Portland State University

PDXScholar

Dissertations and Theses

Dissertations and Theses

Spring 5-27-2016

\title{
Factors Driving the Concentration of Ephemeral Flow
}

Gretchen Anne Guyer

Portland State University

Follow this and additional works at: https://pdxscholar.library.pdx.edu/open_access_etds

Part of the Geography Commons, and the Geomorphology Commons

Let us know how access to this document benefits you.

\section{Recommended Citation}

Guyer, Gretchen Anne, "Factors Driving the Concentration of Ephemeral Flow" (2016). Dissertations and Theses. Paper 2959.

https://doi.org/10.15760/etd.2955

This Thesis is brought to you for free and open access. It has been accepted for inclusion in Dissertations and Theses by an authorized administrator of PDXScholar. Please contact us if we can make this document more accessible: pdxscholar@pdx.edu. 
Factors Driving the Concentration of Ephemeral Flow

by

Gretchen Anne Guyer

A thesis submitted in partial fulfillment of the requirements for the degree of

\author{
Master of Science \\ in \\ Geography
}

Thesis Committee:

Martin Lafrenz, Chair

Britt Crow-Miller

Heejun Chang

Portland State University

2016 


\begin{abstract}
In spite of decades of related research, stream channel initiation is still not well understood. Current theories of channel initiation are grounded in research conducted by Montgomery and Dietrich, largely in the transport limited, temperate, humid climate of the Pacific Northwest, USA. This field data driven work concluded that the drainage area required for channel initiation is directly correlated to the slope of the contributing area. However, there are a host of related variables that have yet to be examined in the field. This study revisits the slope-area relationship focusing on ephemeral overland flow in headwaters of both the Pacific Northwest and an environmentally contrasting island in Greece. By seeking greater understanding of the variables, such as soil properties, vegetation type, and lithology that may influence channel initiation, the study sought to find an equation for remote determination of where ephemeral flow concentrates. However, results indicated that a universal equation does not exist. Rather, the location of ephemeral flow concentration is linked to landscape type, transport versus weathering limited slopes, and corresponding overland flow type. As a result, there is potential for regional models to be developed. Two such models were found as part of this study. One indicates that in a weathering limited environment, Hortonian overland flow is the dominant ephemeral flow type and the driving force behind where it concentrates on the landscape. The other demonstrates that in a transport limited environment, ephemeral flow concentration is due saturated overland flow, with the key to location of concentration being the point of return flow.
\end{abstract}




\section{ACKNOWLEDGEMENTS}

None of the Oregon data so crucial to this study would have been collected without the aid of Dakota Tangredi. His witty banter and shared appreciation for utter silliness made each day of data collection both productive and laughter filled. Similarly, on Kalymnos, this study owes a huge debt to my friend Maria Tsolakidou. She tolerated my incessant questions and chauffeured my body on a scouting expedition to the Vathy Basin in 110-degree heat via a road littered with rock fall. Later, she provided transportation to my northern study site. My gratitude to you both for your assistance and friendship is profound. Thanks also to my friends and family who encouraged me throughout this process. When my life was amuck, and not in a fun soil pit sort of way, you supported me. It will not be forgotten.

I am also thankful for the insights, suggestions, and support of my committee. This study would not have reached its full potential without you. Deep thanks to the Price and Rockie Scholarships for financial assistance that helped enable me to conduct fieldwork both locally and abroad. Great thanks to Martin Lafrenz, my advisor and mentor, for countless chats about all things fluvial that led to a study I believe in. For helping me work out methodology and modifications for Greece and providing a foundation that allowed me to make critical method adjustment decisions, while thousands of miles away with limited internet access, I am indebted. I know I walk away from this experience will greater confidence in my ability to use my knowledge and trust my judgment. 
TABLE OF CONTENTS

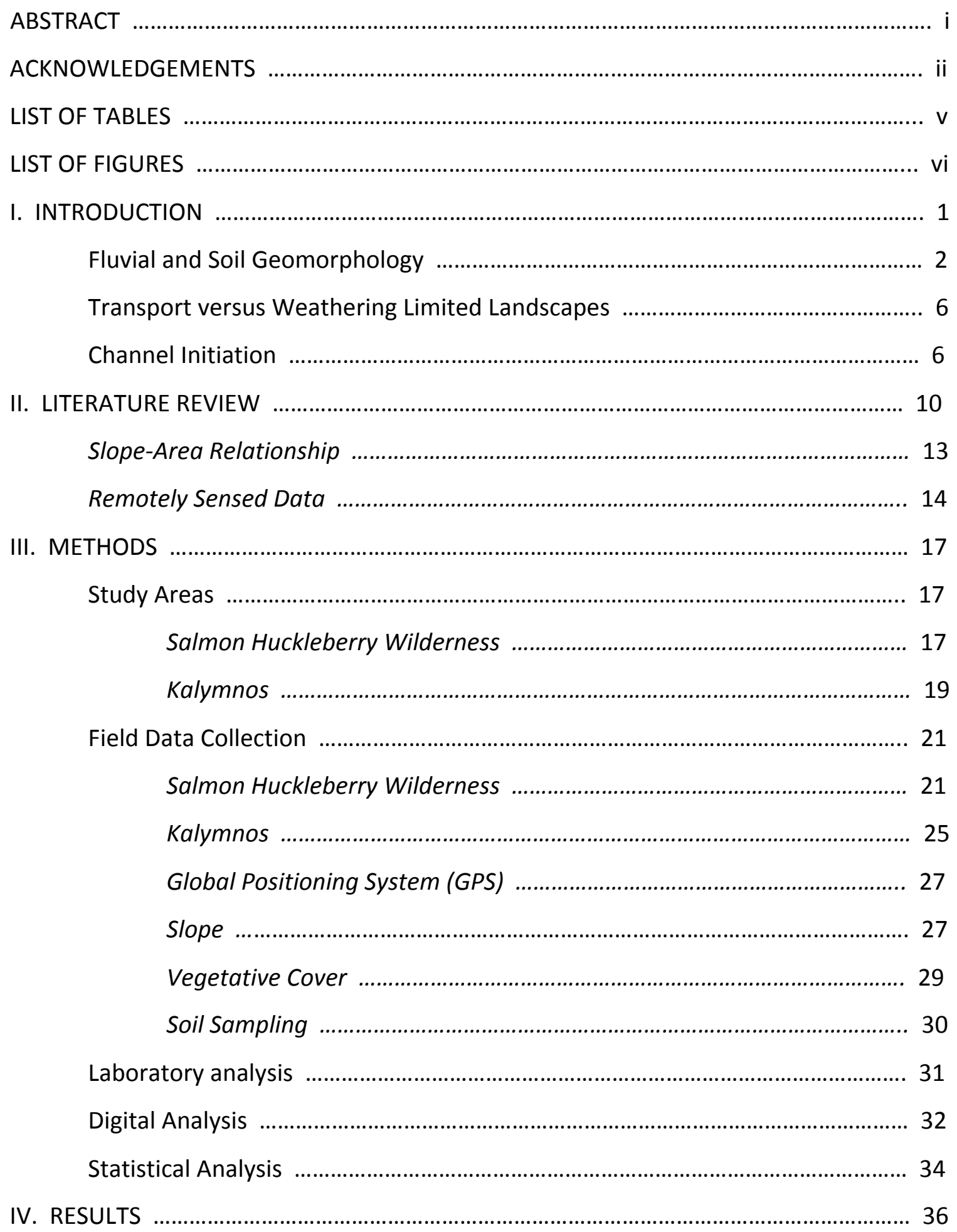


Slope

Soils: Organic Matter, Gravel Content, and Fine Earth Fraction ....................... 37

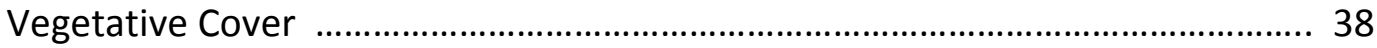

Distance to Drainage Divide ............................................................................. 40

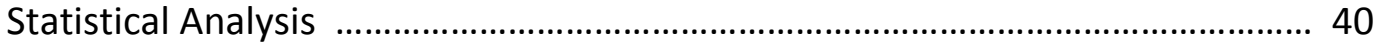

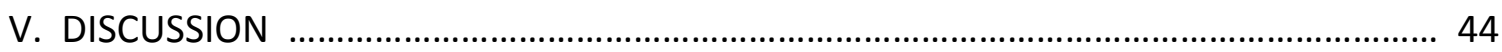

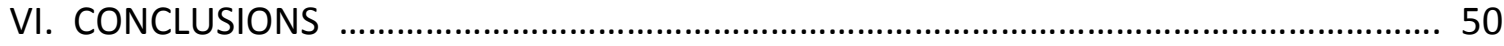

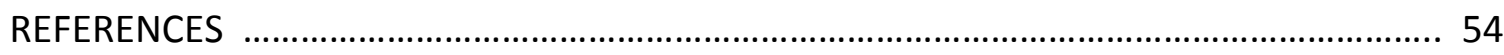




\section{LIST OF TABLES}

\section{TABLE}

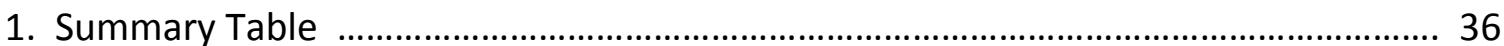

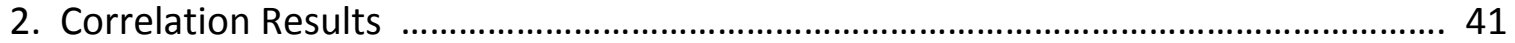

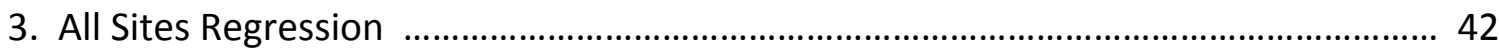

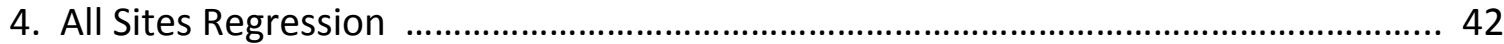

5. Salmon Huckleberry Wilderness Regression ......................................................... 42

6. Salmon Huckleberry Wilderness Regression ........................................................... 43

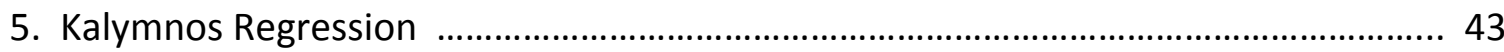

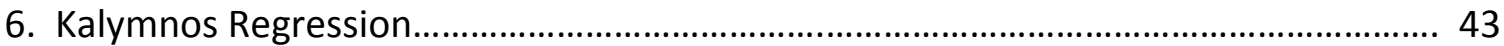




\section{LIST OF FIGURES}

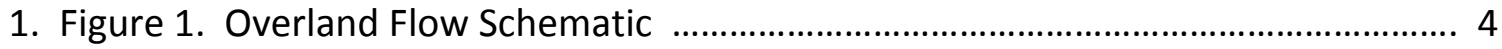

2. Figure 2. Watershed with Channel's Studied by Montgomery and Dietrich ............. 9

3. Figure 3. Study Area in Oregon, United States of America ...................................... 18

4. Figure 4. Typical Old Growth Conditions of Salmon Huckleberry Wilderness .......... 19

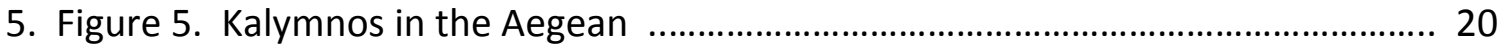

6. Figure 6. Area of Site Locations West of Mount Hood, Oregon ................................ 22

7. Figure 7. Salmon Huckleberry Wilderness Site Locations ........................................ 23

8. Figure 8. Site in the Salmon Huckleberry Wilderness ............................................... 24

9. Figure 9. View from Northern Kalymnos Study Area ................................................. 25

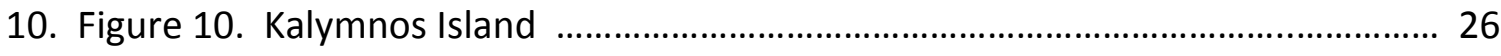

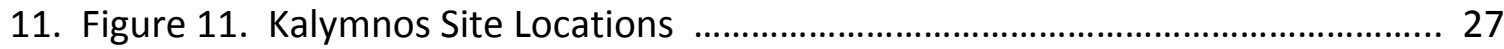

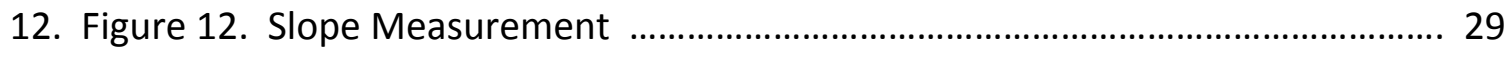




\section{INTRODUCTION}

Over the past several years, studies (Goulsbra et al. 2009, Johnson 2013,Pierce and Lindsay 2015, Vogt et al. 2003) have been conducted seeking to find ways to remotely locate channel heads with varying degrees of success. However, as of yet, research into the farthest upstream location of concentrated ephemeral flow is quite limited. In light of growing awareness of the importance of areas of concentrated ephemeral overland flow to watershed integrity, such a study is timely. In the United States, the Environmental Protection Agency (EPA) has proposed regulation of tributaries under the Clean Water Act, if there is evidence that surface flow is creating a bed and bank (EPA 2015a). As a result of the potential for concentrated ephemeral flow to result in such formation, it is important to determine where on the landscape ephemeral flow concentrates. With climate change altering precipitation regimes, being able to identify causative factors for the location of ephemeral flow concentration has the potential to assist land use managers in making strategic policy decisions over the next several decades. The purpose of this paper is to present fieldwork conducted in the late summer of 2015 on variables hypothesized to influence the location where ephemeral overland flow concentrates, discuss the significance of the findings, and propose suggestions for future work. 
The overarching goal of this study is to provide a method for determining the locations where ephemeral flow concentrates on the landscape, so that resource management strategies can better protect these sources of downstream water. Being able to derive an algorithm to locate these points remotely would be a great benefit to anyone involved with resources management, particularly water quality and quantity.

\section{FLUVIAL and SOIL GEOMORPHOLOGY}

Geomorphology is the study of topographic formations and the processes that form them (Huggett 2011). Importantly, “[...] differences in regional climate, geology, and topography control the general geomorphic processes and ecosystems developed upon a landscape" (Montgomery, 1999, 398). Within geomorphic studies there are various foci, such as: volcanology, glaciology, fluvial geomorphology, and aeolian processes.

Studies of concentrated ephemeral flow lie at the intersection of the geomorphic sub disciplines of fluvial and soil geomorphology. Briefly, the point at which ephemeral flow concentrates is the furthest upslope extension of the channel head. Fluvial processes drive the movement of sediment or litter, which are key to identifying where ephemeral overland flow first concentrates. The impacts of fluvial processes on the soil matrix and the landscape changes that result from erosion are part of soil geomorphology (Schaetzl and Thompson 2015). This collaboration between water and 
soil, erosion and deposition, ultimately determine the morphology of a given drainage basin (Smith and Bretherton 1972).

Once rainwater reaches the surface, it can move according to three patterns. It can infiltrate down into the soil matrix and then move laterally through the soil as throughflow. Water can also infiltrate the soil matrix to the point of saturation. At this time, additional water moves over the soil laterally, as it can no longer infiltrate. This form of water movement is known as saturated overland flow, Figure 1, and it is impacted by antecedent soil moisture but not necessarily by precipitation intensity (Knighton 1998). Often saturated overland flow is found in heavily vegetated landscapes, where there is "a surface stabilized by a dense groundcover and root mat" (Dietrich and Dunne, 1993, 200).

Hortonian overland flow, Figure 1, is less common and requires more specific conditions to occur. Most commonly, for Hortonian overland flow to occur, the rate of precipitation needs to exceed the capacity for the soil matrix to absorb water from the surface. Thus, even if the soil is not saturated, water will move laterally over the surface (Davie 2008). 


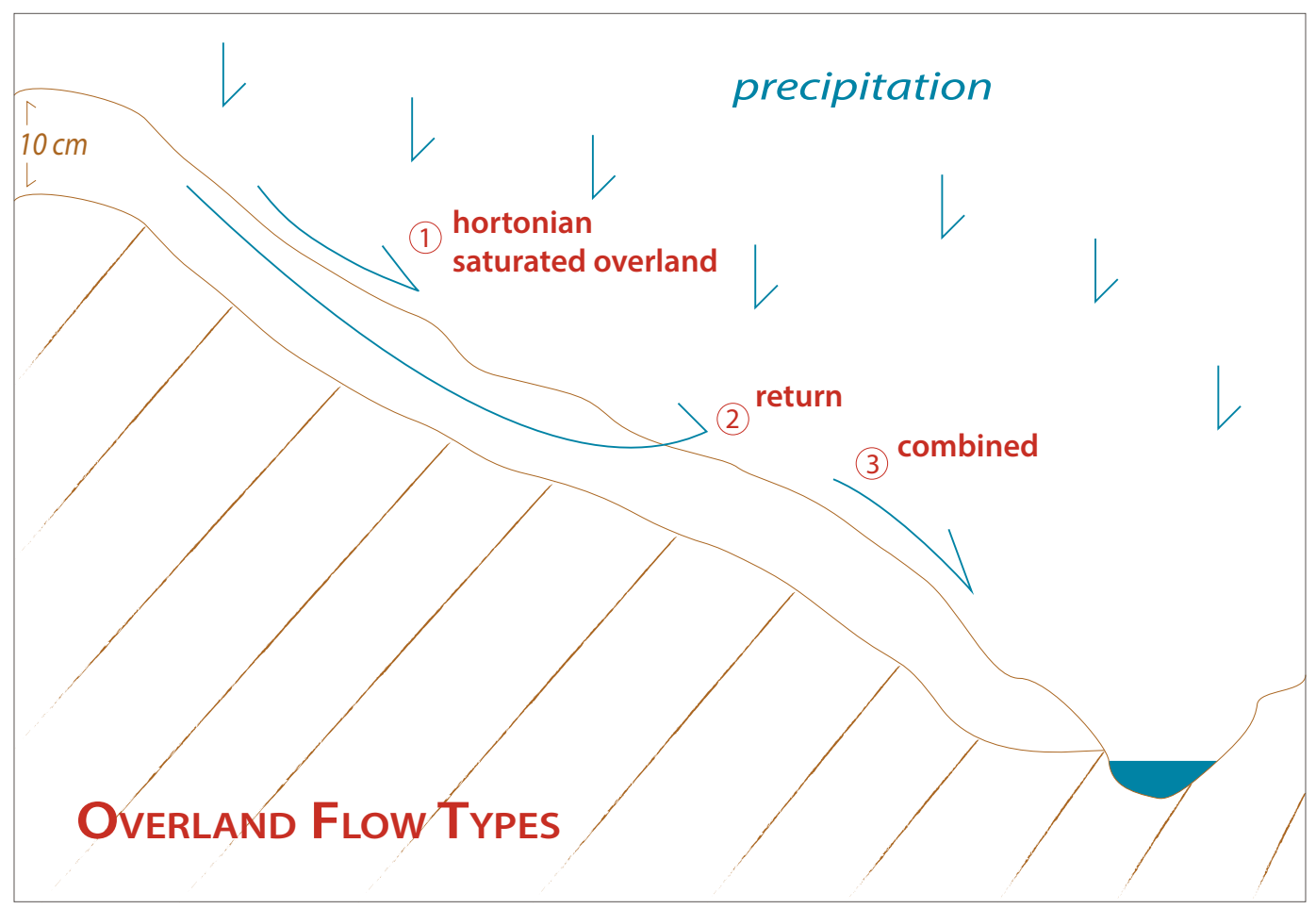

Figure 1. Overland Flow Schematic.

Relating these flow patterns to channel initiation, it is postulated that in more arid environments, Hortonian overland flow is the dominant channel forming flow pattern, while saturated overland flow is dominant on lower angle slopes, in humid climates with thick soils. Furthermore, while one of these forms may be dominant, if a landscape has a variety of slopes and soils these processes can both contribute to channel initiation (Montgomery and Dietrich 1994).

Ephemeral flow is water flow that is directly related to a precipitation event, which normally ceases a few days subsequent (Huggett 2011). In spite of being oft ignored in water resource management, "ephemeral headwater channel systems are 
important to understand because they are primary conduits for water and sediment movement in arid and semiarid landscapes" (Tucker et al., 2006, 959). The Environmental Protection Agency (2015b), in January of 2015, took steps to mitigate this oversight, by officially acknowledging the significance of ephemeral flow contributions to downstream river networks.

Past studies have demonstrated that soil texture is a strong indicator of soil hydrology, more so than topography, drainage pattern, the presence of roots, or soil texture (Cosby et al. 1984). How much water the soil matrix can absorb is directly related to its permeability, which is a function of its texture and vegetative cover. In conjunction with precipitation intensity and duration, these factors dictate what type of flow pattern occurs (Schaetzl and Thompson 2015).

Soil texture and other properties are known to vary depending on slope position and are described using the catena concept. A catena of soils is comprised of soils from each of five slope positions. The summit is at the top, followed downward by the shoulder, backslope, footslope and the toeslope at the base. Typically, fine sediments are more easily removed from higher slope positions, accumulating in the toe slope and leaving the shoulder with a coarser texture (Schaetzl and Thompson 2015). At the same time, the accumulation of litter and soil in "rock crevices and shallow pockets" can occur on particularly steep shoulder positions, known as free faces (Schaetzl and Thompson 2015,471 ). Given that "no one slope parameter is adequate to explain the complexity 
of soil-landscape relationships," (Schaetzl and Thompson 2015, 468) this study examines a variety of potentially significant variables.

\section{TRANSPORT VERSUS WEATHERING LIMITED LANDSCAPES}

Transport and weathering limited hillslopes provide a useful theoretical mechanism for examining landscape evolution. In a transport limited environment the rate of sediment production exceeds its removal, which leads to thick accumulations of regolith and soil. On weathering limited hillslopes, the rate of sediment production is exceeded by its ability to be removed, which produces thin, rocky soils (Huggett 2011; Schaetzl and Thompson 2015).

Due to their soil accumulation, transport limited hillslopes are often associated with higher vegetative cover. On the other hand, weathering limited hillslopes tend to be sparsely vegetated. Furthermore, over time hillslopes are dynamic features experiencing different degrees of both weathering and erosion. Which of the two processes dominate on a hillslope can alter, resulting in shifts from transport to weathering limited landscapes or vise versa (Huggett 2011).

\section{CHANNEL INITIATION}

Due to the fiscal and environmental importance of channel head locations in land use management, they have been increasingly studied over the last decade (Jaeger et al. 2007). In channel initiation studies two major foci emerge, the mechanisms of 
initiation, often related to the type of flow involved, and the location of channel initiation, often termed the channel head. With regard to flow type, it is not uncommon for discussions of channel initiation to be limited to overland flow (i.e. Montgomery and Dietrich 1994). There is sound reason for doing so, because "the development of surface channels is more often associated with overland flow" (Knighton 1998, 26).

While flow types associated with channel initiation may be limited to overland flow, the challenge of defining a channel head remains. Typically, channel head definitions follow that of Montgomery and Dietrich, which requires definable banks, but include caveats depending on how a specific study is conducted (Jaeger et al. 2007, Montgomery and Dietrich 1988). Furthermore, what constitutes an identifiable bank is not without a degree of ambiguity, resulting from determining what qualifies as a steepened bank (Montgomery and Dietrich 1989). This study eschews the parameter of a definable bank. Nonetheless, it owes a great deal of its understanding of channel heads to research working with this general definition, because this definition is based on morphological observation, which allows for identification regardless of the presence of flow (Dietrich and Dunne 1993) and fits well with the current EPA definition (2015a).

In discussing studies of channel initiation, it is important to have some understanding of headwater streams. In an emerging pattern, one finds that like channel heads, headwater streams are defined in a variety of ways. Frequently, in order to be deemed headwater streams not only are steepened banks required but also perennial or intermittent flow of a specified duration (Nadeau 2015). However, Lowe 
and Likens present a definition that is expansive enough to include points of concentration of ephemeral overland flow. In speaking of stream networks, they state, "the finest of these networks, beginning where water flowing overland first coalesces to form a discernable channel, are called head-water streams" $(2005,196)$. It is possible that sites examined in this study fit their definition. Likewise, a 2015 (Placzkowska et al.) study on the spatial distribution of channel heads in Poland, expands on Montgomery and Dietrich's classic definition to state, "a channel head is the upper boundary of fluvial processes" (240). Again, while conceptually inclusive of the location where ephemeral flow concentrates, to avoid potential confusion, this study refrains from deeming locations of concentrated ephemeral flow channel heads.

For the sake of visual clarification see Figure 2 where channels, as identified by Montgomery and Dietrich, are dark lines. The upslope end of the line represents channel head, per their definition. The point furthest upslope of their channel head in the stippled area represents the point of ephemeral flow concentration. 


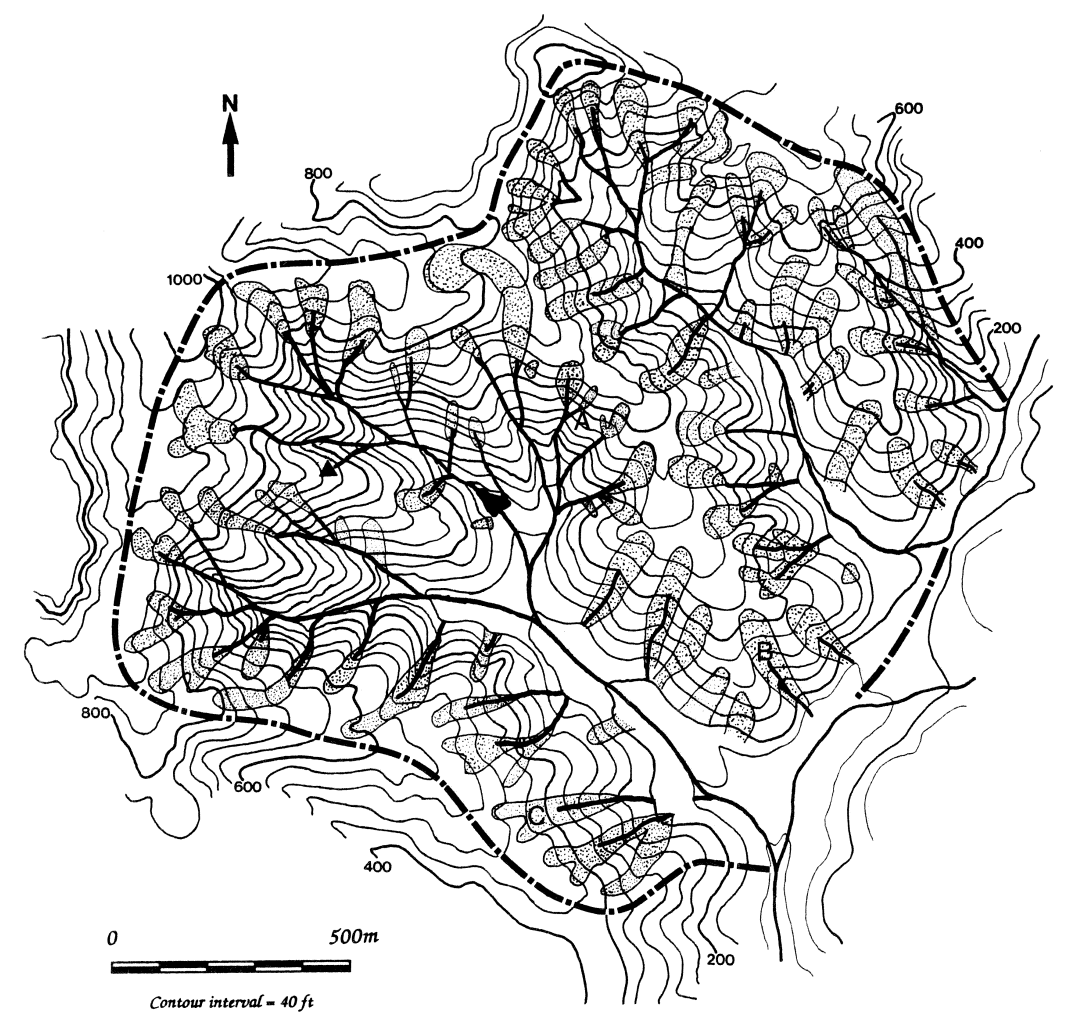

Figure 2. Watershed with channels studied by Montgomery and Dietrich (1989).

Since concentrated ephemeral flow is directly linked to channel heads and headwater streams, it follows that concentrated ephemeral flow is subject to the same susceptibility to disturbances as headwater streams (Lowe and Likens 2005). In addition, headwaters also are often discontinuous and this discontinuity is what often differentiates them from the larger watershed of which they are part (Gomi et al. 2002). Likewise, ephemeral overland flow is often discontinuous and suffers the same lack of understanding that headwater streams do. It is likely the reasons for this are similar, as both "are small and numerous," which results in the significance of their contributions to the larger hydrological network being "underestimated and inadequately managed" (Gomi et al. 2002, 905). 


\section{LITERATURE REVIEW}

In their work on channel initiation Montgomery and Dietrich (1989) suggest that the dominant mechanisms of channel initiation are linked to slope angle, with saturated overland flow being more important at low angles. Furthermore, one early study conducted in the Pacific Northwest reveals an inverse relationship between the slope and contributing area required for a channel head to form (Montgomery and Dietrich 1988). In other words, on steeper slopes, less area is required for a channel to commence. Taking their findings a step further, they postulate that, "because runoff must increase with increasing drainage area, [...] for a given slope, the source area size required to initiate a channel should increase with increasing aridity $[\ldots]^{\prime \prime}(1988,234)$. However, the strength of the slope-area relationship they found has been subsequently questioned, due to the amount of scatter found among the results from their eighty sites (Jaeger et al. 2007).

A decade after Montgomery and Dietrich's (1998) seminal study, David Knighton, suggests that with overland flow driven channel heads the distance from the drainage divide is variable. However, in spite of this variability, Knighton (1998) goes on to state, "the concept of a critical distance or contributing area remains relevant" (36). In this way, he embraces the variability found in study results, while maintaining the importance of such studies. 
Predating the work of Montgomery and Dietrich, R. J. Huggett's (1975) work in soil geomorphology addresses valley basins. These valley basins are not synonymous with drainage basins or contributing areas, but are a subset thereof. A key distinction is that a valley basin can be dry and not contain a continuously flowing stream. In acknowledging the geomorphic presence of valley basins, independent of flow, Huggett opens the door for a discussion of ephemeral headwater contributions to drainage networks.

Focusing on the variation in elevation and aspect between channel heads, a study in the Front Range of Colorado (Henkle et al. 2011), found that aspect has no influence on the location of channel initiation. Using statistical analysis, Spearmans correlation and linear regression analysis, the study finds that contributing area, slope, and basin length combined could account for approximately half of the variability in their results. In addition, elevation and precipitation are significant to the variability they found (Henkle et al. 2011). These findings combined with others, such as those of Jaeger et al. (2005) that found bedrock features to have some influence on channel head locations, suggest that channel initiation and the locations where ephemeral overland flow concentrates are the result of complex topographic and climate relationships.

In 2012, Julian et al. conducted a study in forested watersheds of Mid-Atlantic States in the USA. They mapped channel head locations in five areas in the field, using Montgomery and Dietrich's definition, and performed the rest of their data collection 
using available remotely sensed data, which included vegetation cover and DEMs for elevation and related data. The focus was on finding statistical relationships among the variables they examined. Of their findings, the most notable is that as the combined silt and clay percentage increased, the contributing area decreased throughout all of their study sites (Julian et al. 2012).

Mapping fifty channel heads in two catchments in the Front Range of Colorado, USA that were burned in 2012, Wohl (2013) compared the contributing areas for channel heads in the burn region with ones that had not been burned. The contributing areas for the burnt channel heads are significantly less than they were prior to the burn based on calculations made using information available via the USGS's Stream Stats. In addition, all of the flow at the burn sites is overland flow.

Focusing specifically on ephemeral flow's influence on stream network expansion and contraction, researchers Pierce and Lindsay (2015) use electrical resistance sensors to monitor temporal changes. These sensors allow them to monitor the spatial and temporal fluctuations of ephemeral flow in three streams in Ontario, Canada. Causality for fluctuations is different for each of the three studied streams. Furthermore, their results indicate no pattern to the expansion and contraction of flow networks. This finding is unexpected given that the three streams belong to the same subcatchment. As a result, they recommend that future studies include soil texture and compaction analysis. They also note the complex nature of ephemeral flow and the fact that controls can be diverse, even within a single catchment. 


\section{Slope-Area Relationship}

As a result of Montgomery and Dietrich's, 1988 study, much channel initiation work references the slope area relationship they found. Typically slope references the local slope, measured in the field directly upslope of the channel head, and area refers to the contributing or drainage area. In the field, at the site of channel initiation, contributing area is defined "as the area upslope of the measurement location" (Montgomery and Dietrich 1992, 827). Expanding that definition a bit, the contributing area, frequently called the source area, refers to "the area, [sic] which contributes water to a particular channel or set of channels" (Leopold et al. 1964, 131). Frequently the term drainage basin is used synonymously with contributing area and source area, although at times it is defining a larger area.

The slope-area relationship suggests that as the local slope increases the amount of land area required for channel initiation decreases (Montgomery and Dietrich 1988). If such a change occurs, in theory, the density of channels will increase (Montgomery and Dietrich 1992). However, much subsequent work has called these finding into question, not only due to the aforementioned scatter, but also due to conflicting findings (Imaizumi 2010; Jaeger et al. 2007; Placzkowska et al. 2015).

In a 2007 (Jaeger et al.) study of eighty-one channel heads, there is no clear slope-area relationship. Some locations have a moderate positive relationship, others a moderately inverse relationship, while still others have no relationship whatsoever. For 
one of the Julian et al. (2012) study areas, the largest contributing areas are also the steepest. Overall, Julian et al. (2012) shows that slope has varying relationships with contributing area throughout their study areas.

Like both of the aforementioned studies, a 2010 (Imaizumi et al.) study in the mountains of Japan, uncovers variable slope-area relationships. In study locations with high surface roughness, there is a relationship between slope and source area. In areas with low surface roughness, there is no relationship. Furthermore, the processes controlling the location of channel initiation vary per catchment and the dominant type of flow in a catchment is more important to the location of channel initiation than the volume of available sediment. These findings add to the growing body of evidence suggesting the slope-area relationship found by Montgomery and Dietrich is far more complex than initially suggested.

\section{Remotely Sensed Data}

With regard to remotely sensed data, a study conducted in Poland, finds conflicting results between field and digital elevation model, DEM, generated measurements. Using field measurements, they find a negative relationship between slope and contributing area for their study area. This correlates with the findings of Montgomery and Dietrich. However, using the same study sites, they found a positive relationship when local slope and contributing area where derived via DEM. These 
findings point to the importance of field measurements until there is better correlation between field and digital results (Placzkowska et al. 2015).

Similarly, Vogt et al. (2003) sought to find methods capable of handling the scalar limitations of remotely sensed data, when dealing with small watersheds. A key limitation to existing digital methods is that they do not account for landscape variability. Existing methods assume a constant threshold for contributing area. The portions of a channel network most impacted by the limitations of current digital methods are flat terrain and points of channel initiation. In order to increase model accuracy, Vogt et al. (2003) went about creating five different landscape types, focusing on environmental factors, such as: percent surface cover (based on CORINE Land Cover Data), relief, and lithology; they consider critical controls on channel initiation. By taking environmental factors into account, they were able to improve model accuracy. Nonetheless, the limitations connected with DEM resolution continue to obscure topographic details. Furthermore, their improved modeling remains incapable of addressing the complexities of karst environments.

Specifically addressing DEM resolution in relation to GIS methods of channel network extraction, Ariza-Villaverde et al. (2015), investigated the algorithms used by GIS software to extract contributing areas. They paid special attention to the most userfriendly and, thus, most commonly used algorithm, D8. D8 is the default for ArcGIS, a GIS program frequently employed in hydrological work. Ultimately, they used multifractal analysis to generate site specific threshold values for flow accumulation and 
consequently derive drainage networks. However, if one is going to use ArcGIS to locate channel heads, they recommend the use of high resolution DEMs to help counteract the shortcomings of D8.

When locating channel heads via digital terrain model (DTM) Imaizumi et al. (2010) note that the lack of a clear slope-area relationship could be due to DTM limitations. Unlike most studies, they attempt to calculate the local slope using the DTM instead of measuring it in the field. In doing so, Imaizumi et al. (2010), reveal that obtaining local slope measurements from the DTM is unreliable, even more so than the DTM derived contributing areas.

In spite of the limitations of DEM resolution, there has been some progress toward affordable methods related to the monitoring of ephemeral flow. Goulsbra et al. (2009) performed a study making use of electrical resistance sensors. The sensors are designed and used to determine if ephemeral flow is present along portions of their study catchment, at a given time. Ultimately, they set up the sensors in a way that allows for accurate, easily interpretable readings. While only tested on a single catchment in a wetland environment, the affordability of these sensors could lead to expanded studies and greater understanding of ephemeral flow. 


\section{METHODS}

During July and August of 2015, I collected data in the Salmon-Huckleberry Wilderness of Oregon, USA. After finishing collecting these data, I collected data on the island of Kalymnos, Greece, during September 2015. Data representing forty-five unique sites were collected. The two study areas were chosen to represent both a strong contrast between the variables being examined and a transport and weathering limited landscape, as well as areas with comparatively less anthropogenic influence. GPS location, local slope, vegetative cover, and a composite soil samples were collected for each visually identified, ephemeral overland flow initiation point. Soils were then analyzed using United States Department of Agriculture (USDA) soil analysis procedures and all resultant data was statistically analyzed for correlations, co-linearity, and regression relationships.

\section{STUDY AREAS}

\section{Salmon Huckleberry Wilderness}

The Salmon Huckleberry Wilderness is located to the south of Mt. Hood, Oregon. It is managed by the Forest Service, which restricts access via permit, and has been a designated wilderness area since 1984 (Wilderness Institute 2016). (Figure 3). 


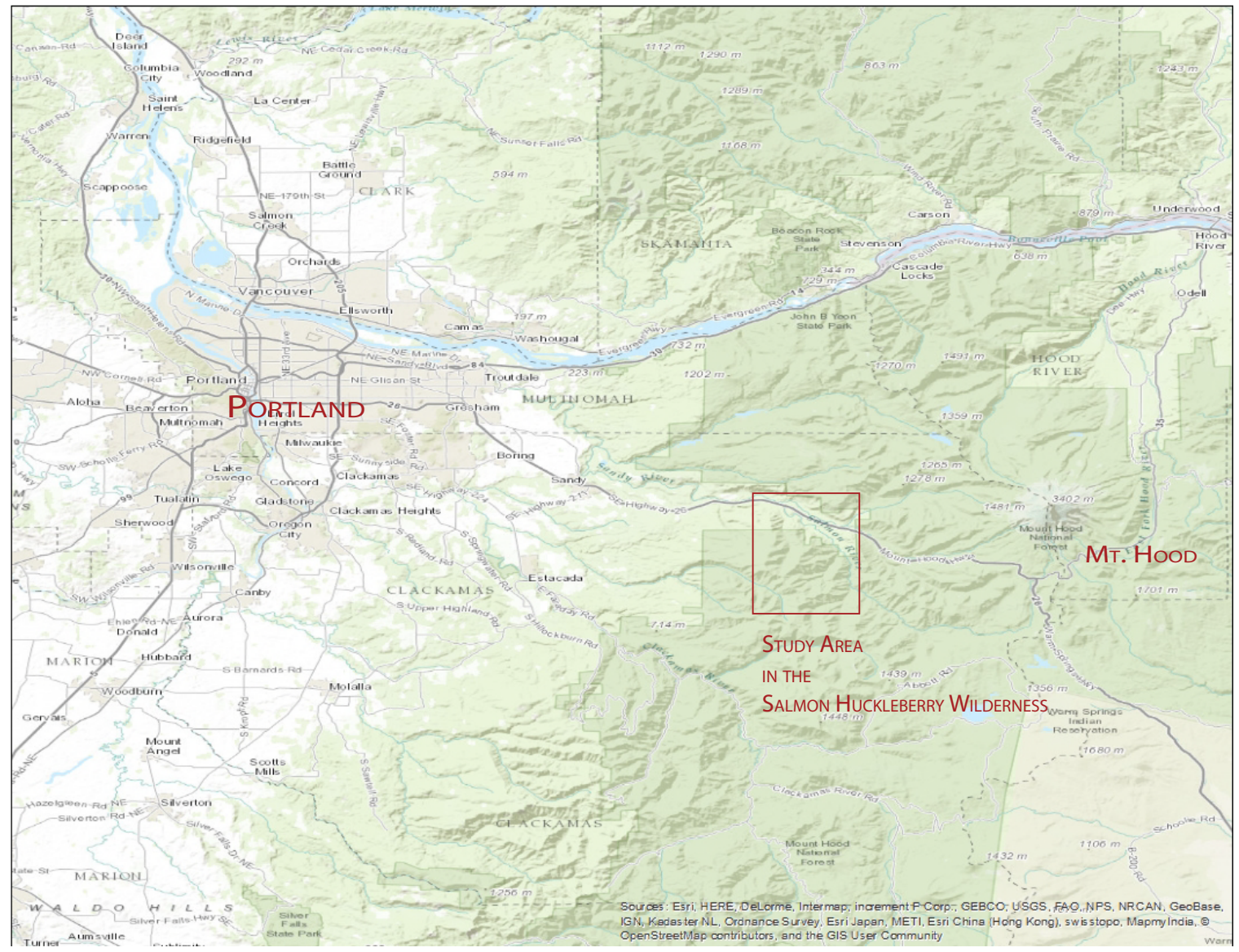

Figure 3 - Study Area in Oregon, United States of America. Map made using ArcGIS basemap.

The parent material of the Boulder Creek Watershed area in the SalmonHuckleberry Wilderness is largely volcanic ash atop basalt and andesite derived colluvium (USDA 2015). Geomorphically, the Salmon-Huckleberry Wilderness represents a transport limited hillslope.

Vegetation is generally thick and includes pockets of old growth forest that have survived regional burns (USDA 2016). “Douglas fir, true firs, western red cedar, and western hemlock" are the dominant tree species (Figure 4). Understory vegetation is dense (Wilderness Institute 2016). According to the National Weather Service, the 
Boulder Creek watershed receives between 1800 and $2540 \mathrm{~mm}$ of rain per year

(National Oceanic and Atmospheric Administration 2016).

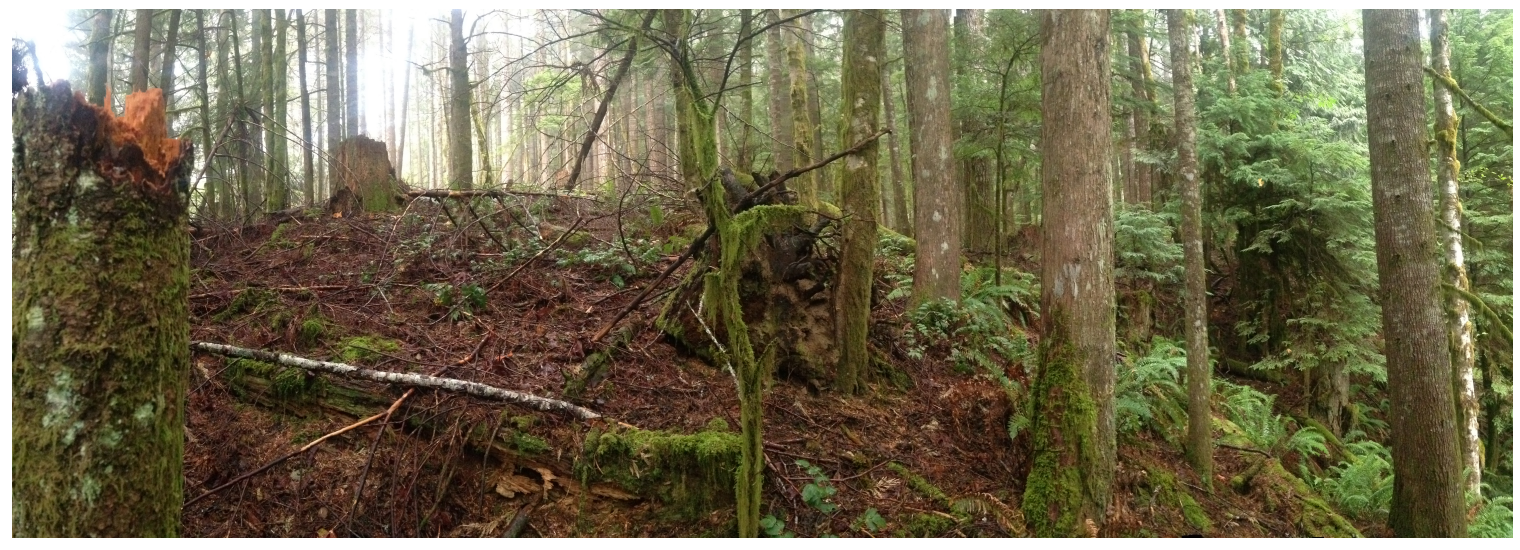

Figure 4 - Typical old growth conditions in the Salmon Huckleberry Wilderness. Photo by Gretchen Guyer.

\section{Kalymnos}

Kalymnos $\left(36^{\circ} 57^{\prime} \mathrm{N}, 26^{\circ} 59^{\prime} \mathrm{W}\right.$ ) is located in the Aegean Sea off of the southwestern coast of Turkey (Mimides et al. 2007) (Figure 5). It is the fourth largest island of the Dodecanese islands off of the southwest coast of Turkey (Kechagias and Katsifarakis 2004). Historically, the island was known as a hub for the sponge diving trade, which has virtually disappeared due to the dangers associated with free diving and North African nations closing their waters to Greek divers (Kamm 1984). 


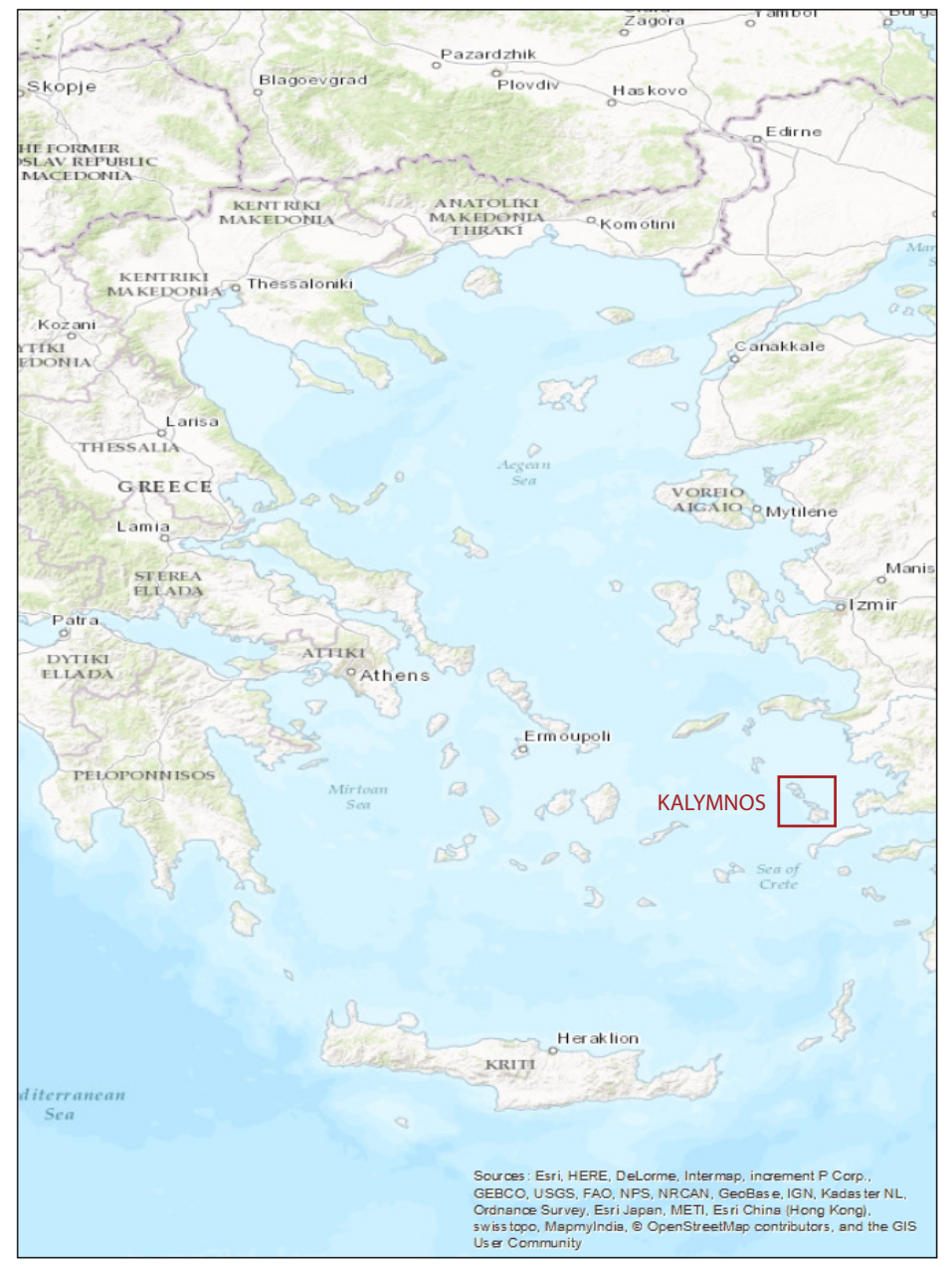

Figure 5. Kalymnos, Greece in the South Aegean Sea. Map made using ArcGIS basemap.

Most of Kalymnos in underlain with permeable limestone (Kechagias and Katsifarakis 2004). One portion of the island is an ancient volcano and the lower elevations of the Vathy basin have alluvial deposits as parent material (Mimides et al. 2007). However, all study sites are located in regions with limestone parent material. In contrast to the Salmon-Huckleberry Wilderness, Kalymnos represents weathering limited hillslope geomorphology. 
The majority of vegetation in the study area is located where soil is present. Soil typically accumulates in crevices between and pockets within exposed bedrock. The island is considered barren outside of herbaceous shrubs. Thyme, oregano, and sage are dominant species (Greece.com 2016). Plant growth on the island tends to occur in conjunction with the wet season (Mimides et al. 2007).

As there is no weather station on Kalymnos, climate data are compiled from weather stations in Samos to the north $(80 \mathrm{~km})$ and Rhodes to the southeast $(107 \mathrm{~km})$. The rainy season is from October/November until February with the hottest months being from June until September. Generally, the warm months are dry, while the wet months are cool. The climate is considered "warm, dry Mediterranean" (Mimides et al. $2007,1478)$. Rainfall is the only form of precipitation and is comparatively low, with a noted average of around $521 \mathrm{~mm}$ per year (Mimides et al. 2007). While annual precipitation is relatively low, evapotranspiration is relatively high (Kechagias and Katsifarakis 2004).

\section{FIELD DATA COLLECTION}

\section{Salmon-Huckleberry Wilderness}

Anticipating the locations of ephemeral flow to be relatively close to ridgelines, I chose an area of the Salmon-Huckleberry Wilderness that has trails near the ridgeline. Using online maps (Wilderness Institute 2016; USDA 2016) and an unsuccessful attempt to access the area via Bureau of Land Management, BLM, roads to the west, I narrowed 
my study area to sites accessible via the Boulder Ridge trail, which commences at the Wildwood Recreation Site $\left(45^{\circ} 21^{\prime} 22^{\prime \prime} \mathrm{N}, 121^{\circ} 59^{\prime} 12^{\prime \prime} \mathrm{W}\right)$. These twenty-five sites are all upslope of BLM land and are on National Forest lands (USDA forest service .pdf trail maps) (Figure 6 and 7). The area is heavily vegetated, old growth forest, with current anthropogenic influence limited to the narrow, unpaved trails. Understory vegetation generally decreases with increasing elevation.

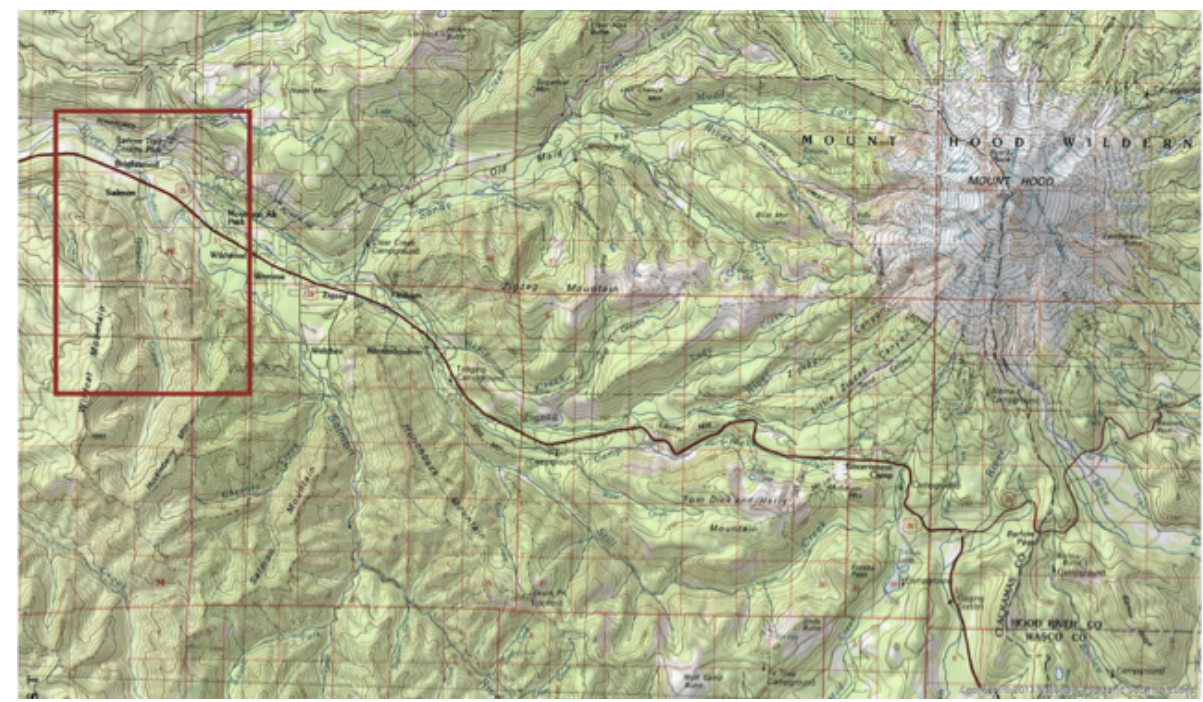

Figure 6. Area of site locations, west of Mount Hood, Oregon. Map made using ArcGIS basemap.

Once in the wilderness, I selected sites by visual assessment. This visual method is an extension of the methodology Montgomery and Dietrich used for their work. A notable difference is that my sites lack banks as typically defined by visible steepening. However, I typically found my sites by first identifying a Montgomery and Dietrich channel head with bank steepening. I then followed it upslope, until evidence of litter movement and/or erosion ended. All sites identified as the location where ephemeral flow concentrates are permanent channels. Thus, although the flow in them is ephemeral, their presence on the landscape is not. 


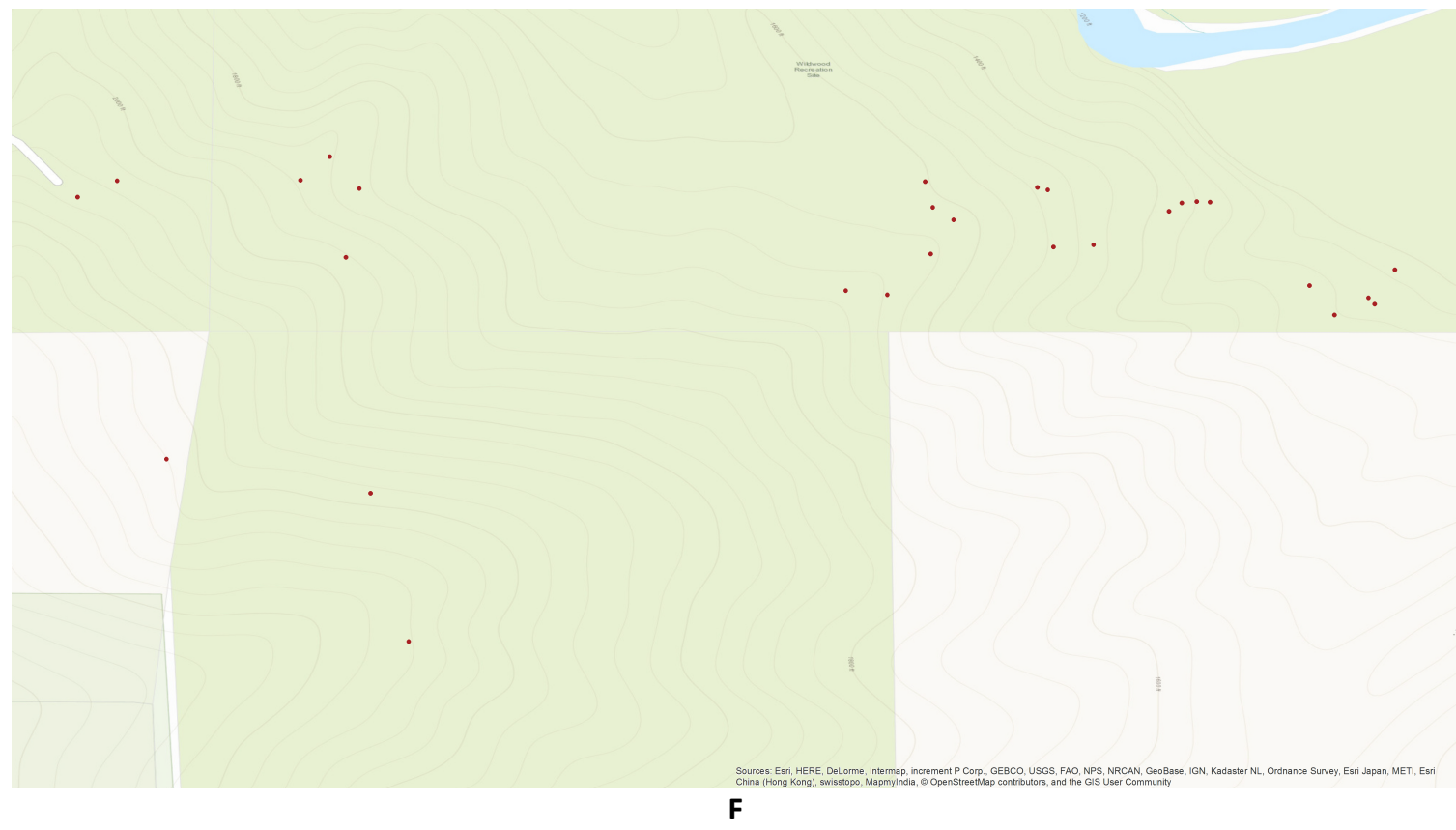

Figure 7. Site locations within the Salmon Huckleberry Wilderness. Map made using ArcGIS basemap and collected GPS data.

Like Montgomery and Dietrich and later Jaeger, I included discontinuous sites (1988; 2007). With discontinuous sites, I used the furthest upslope location (Montgomery and Dietrich 1989). At the same time, I was careful to ensure these sites discernably reconvene downslope. If a clear flow pattern is not discernable or evidence of litter and/or soil movement is unclear, I did not collect data. (Figure 8). 


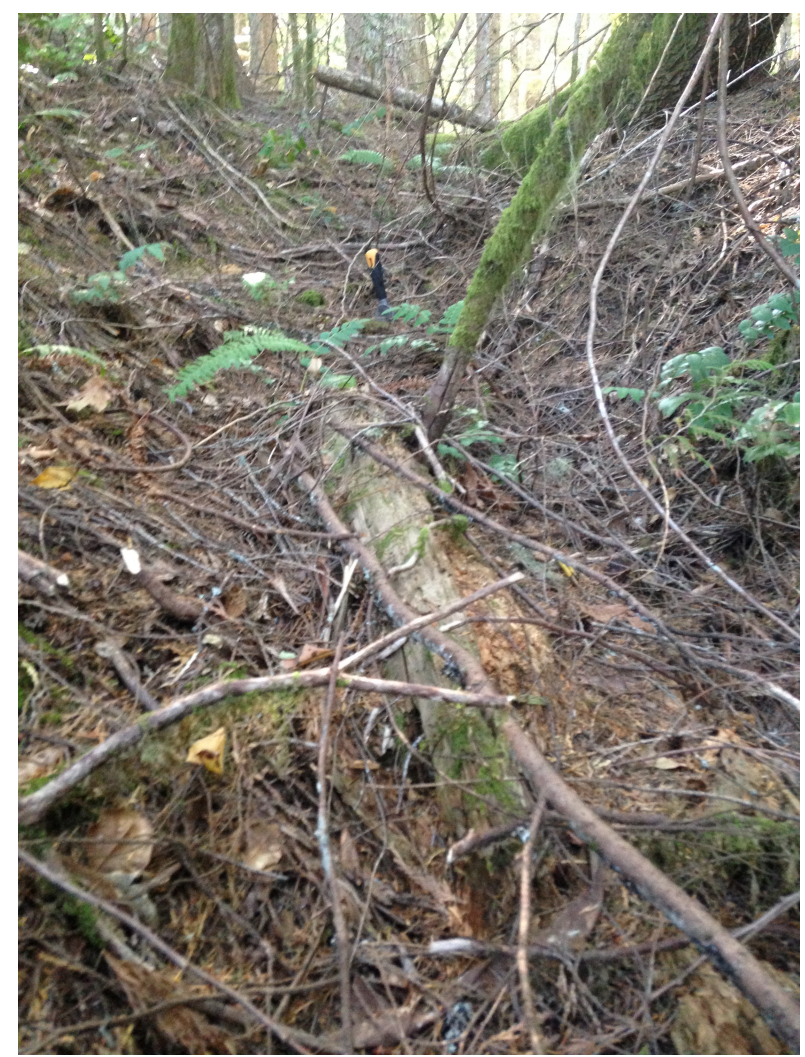

Figure 8 - Site in the Salmon-Huckleberry Wilderness. Trowel handle for scale.

Even channel heads with definable banks are known to have variable flow commencement points (Jaeger et al. 2007). Like channel heads, a point of concentrated ephemeral overland flow "is a morphologic feature independent of the seasonal presence of surface water" (Jaeger et al. 2007, 783). Thus, I collected data in summer, dry months in order to focus on morphological identification of concentrated ephemeral overland flow. In addition, I chose sites that showed no evidence of being the result of mass wasting or fluctuations in the water table.

I also attempted to select sites at a variety of elevations. Due to the tendency of trails to increase soil erosion, I omitted channel heads downslope from trails in both 
locations (Huggett 2011). This decision parallels that of Montgomery and Dietrich (1989) in their work on channels heads.

\section{Kalymnos}

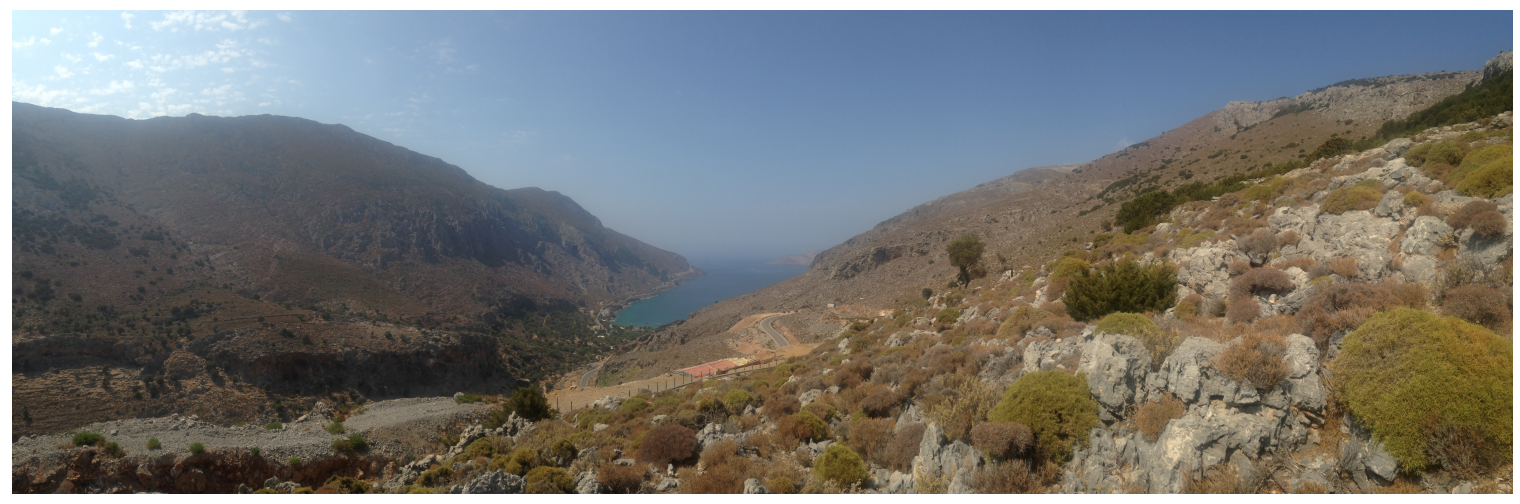

Figure 9 - View from a site in the Northern study area on Kalymnos near east of Arginoda.

On Kalymnos, the methodology used in the Salmon Huckleberry Wilderness was employed, with modifications, as detailed below. Data on Kalymnos were collected from two general areas, one to the southwest of the town of Myrties (fifteen sites) and the other to the north of the road connecting the west coast of the island to Vathy (five sites). The second area is roughly due east of Arginoda (Figure 9, 10, and 11). These areas were chosen using a GPS referenced topographic map of the island (Psimenos 2015). In total, data were collected from twenty sites on Kalymnos. 


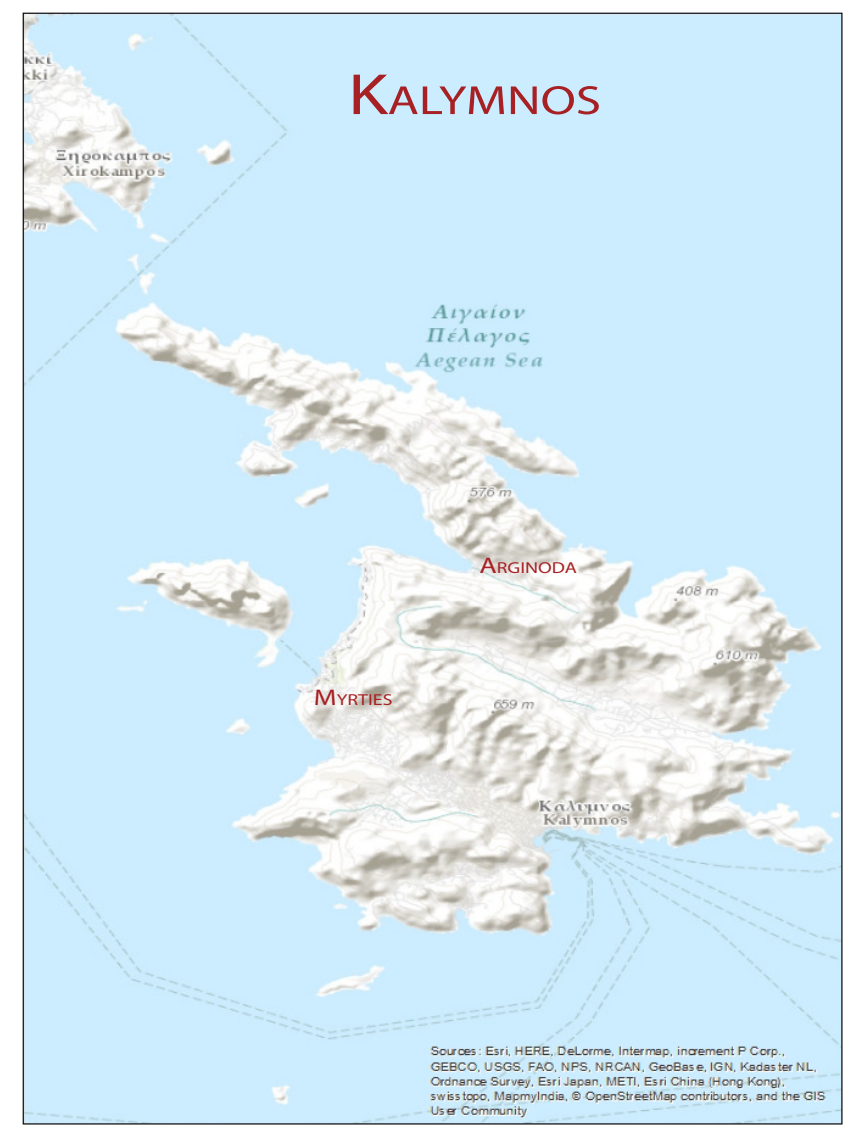

Figure 10. Kalymnos Island. Map made using ArcGIS basemap.

Both areas have rough trail access, but are not developed climbing sectors.

These trails are goat paths that are increasingly used to access remote climbing sectors.

They are narrow and unpaved. In addition, semi-wild goats roam the area.

Unlike the Salmon-Huckleberry Wilderness, site selection for diverse elevation was limited, due to abandoned terracing over all but the steepest terrain. It is acknowledged that there are ephemeral headwater streams among the terraced 
portion, but the terraces inevitably influence their flow paths. In light of this fact, I was careful to avoid any sites potentially influenced by terracing.

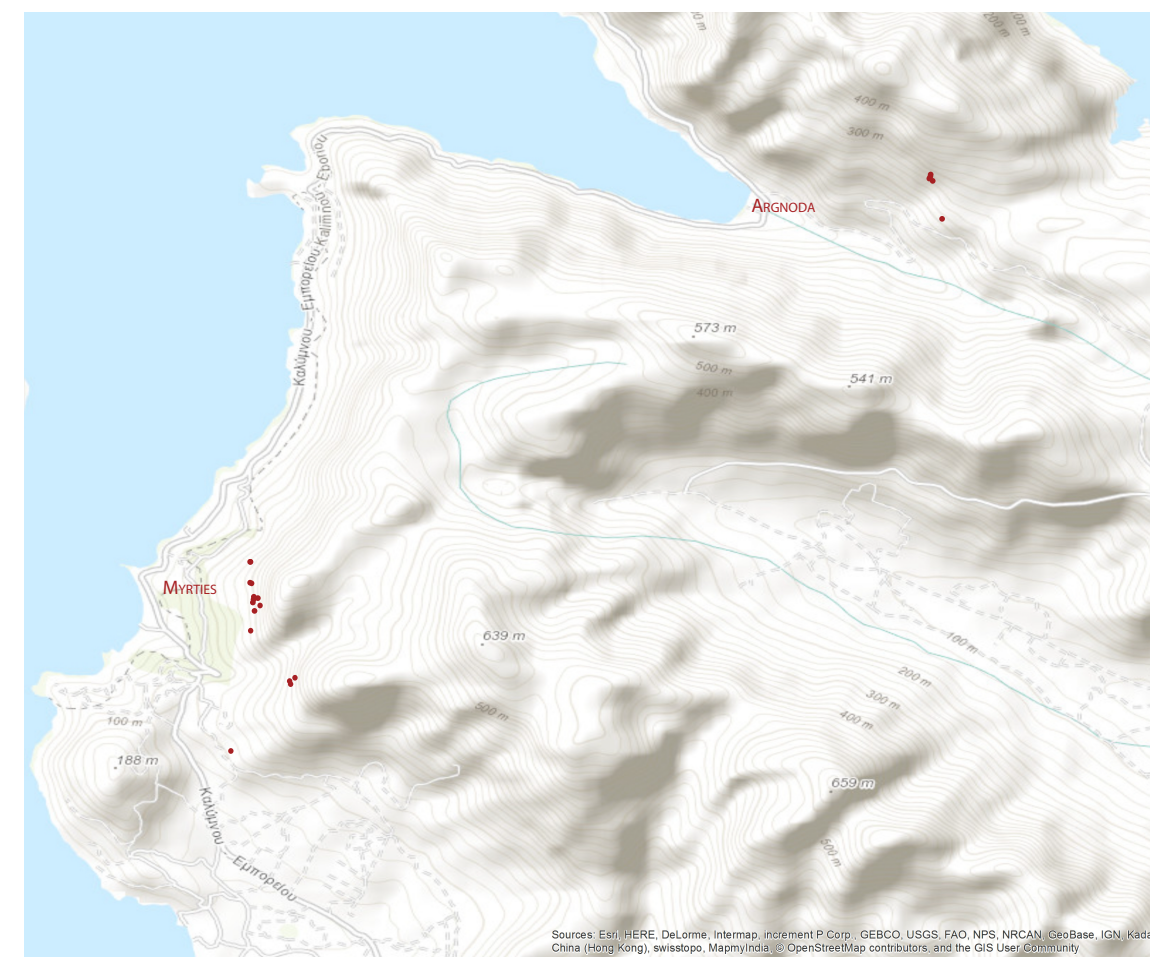

Figure 11. Kalymnos Site Locations. Map made using ArcGIS basemap and collected GPS data.

Global Positioning System (GPS)

Once sites were identified, the location of ephemeral channel initiation was mapped as a point with a Trimble GPS Juno 3B. In an attempt to minimize multipath errors, I attempted to collect at least 20 points per site.

Slope

At each site, I measured local slope. The choice to measure slope in the field is based on the fact that this is the most commonly used method. It is the method 
established by Montgomery and Dietrich, which measures local slope directly upslope from the site (Henkle et al. 2011; Jaeger et al. 2007; Montgomery and Dietrich 1988, $1989,1992)$. Furthermore, the choice to measure local slope in the field is also influenced by studies noting that deriving local slope from DEM is problematic due to issues with DEM elevation data sets (Roth and Barbera 1997).

On each data collection day, I measured the height of my eye from the ground for later use in calculating vertical distance. When possible local slope was measured at a two meter distance. If the terrain is too steep for a measurement at two meters, I measured local slope at a one or one and a half meter distance. This two meter distance was measured horizontally, directly upslope of the site. Then a measuring stick was placed on the ground at the two meter distance, while I stood at the site and used an eye level to read the measuring stick height (Figure 12). This height minus my eye height is the vertical height. Later, I calculated the local slope as a percent (rise/run*100). 


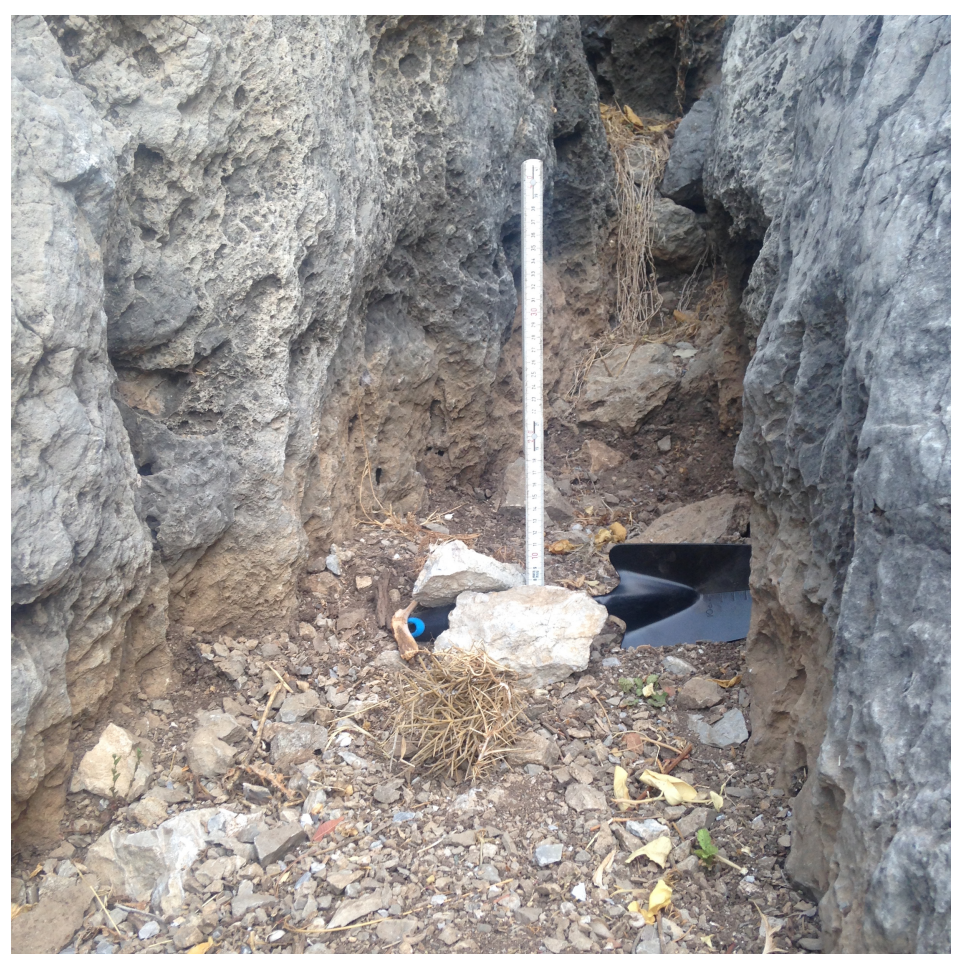

Figure 12 - Upslope point of measurement. Kalymnos.

\section{Vegetative Cover}

For each site, I analyzed vegetative cover in three locations upslope from the site using the Daubenmire Cover Class method (Daubenmire 1959). All cover areas are still within the contributing area to the same ephemeral headwater. A PVC pipe square outlined the area for assessment. In the Salmon-Huckleberry wilderness, the PVC pipe square was a square meter. In order to transport the PVC pipe to Kalymnos, the square was downsized to a quarter meter.

I preformed the first assessment at the point two meters upslope from the site; the place where the measuring stick was set up for the local slope calculation. The next two were done to the right and left of the first and were selected via a random toss. 
While random, I was careful not to toss the PVC pipe square out of the contributing area of my ephemeral headwater. This caution is crucial given the small size of the contributing areas and my observation that it is not uncommon for ephemeral headwaters to be within a few meters of each other.

\section{Soil Sampling}

At each site, three soil samples were taken and combined to create a composite representative sample. A soil sample was taken from within the square used for the vegetative cover analysis. I attempted to collect from the center of the square for each of the three subsamples, since "soil geomorphology is a field-based science; [sic] knowledge of landforms in the field is essential to obtaining a representative soil sample, for most applications. No amount of laboratory work, 'number crunching,' or library or online research can make up for poor site selection or sampling technique" (Schaetzl and Thompson, 2015, 446). In the Salmon-Huckleberry Wilderness, samples were collected to a depth of ten centimeters, after excluding dense litter, when necessary. I used a trowel with depth markings at every two centimeters and attempted to collect cylindrical samples. Soils were sampled from the near surface, epipedon, instead of at a greater depth, as overland flow is a surficial process. As a result, data about epipedon soils is most relevant.

On Kalymnos, depth to bedrock or impenetrable layer was also noted using the trowel centimeter markings that are etched into the trowel. In many instances, one or 
more of the areas for soil collection are bare rock. Even more commonly, when there is soil, it is located in small shallow depressions in the rock. In these instances, what soil could be removed was and I noted when soil was absent for a subsample. Fortunately, I was able to retrieve soil from at least one of the subsample locations, for all but one site.

\section{LABORATORY ANALYSIS}

Soil samples from the Salmon-Huckleberry Wilderness were analyzed in the soils lab of Portland State University's Geography Department. When speaking of soil samples from this point forward, the term is referring to the composite sample, unless otherwise specified. Methods for soil analysis were largely derived from the USDA's 2014 Soil Survey Field and Laboratory Methods Manual, unless otherwise noted. First, gravel, large liter and organic matter were separated from the fine earth fraction using a $2 \mathrm{~mm}$ sieve. Gravel was then separated from the large organic particles and weighed. In order to get an idea for my personal accuracy in hand texturing, I hand textured about half the Salmon-Huckleberry Wilderness samples, following the USDA's (2014) flowchart. Then, the soil samples were dried for at least 24 hours in a 105 degree Celsius oven.

After drying, each sample was fired in a 440 degree furnace for at least 24 hours. As samples appeared to contain a very high percentage of organic matter, I fired as much of the sample as I could fit into the largest size crucible the furnace allowed. I 
weighed each crucible when empty, with the soil sample prior to firing, and with the soil sample after firing. Using these measurements, I calculated the percent organic matter for each sample by first determining the weight of the sample before and after firing.

After all samples were fired to remove organic matter, I then used the micropipette method as modified by Lafrenz (2015) from Burt, Reinsch, and Miller (1993) and Burt (2009) to determine the fine earth fraction of each sample. After determining the percent sand, silt, and clay, I used the texture triangle to determine the soil type (USDA 2014).

Due to permitting issues, I was unable to bring Kalymnian soil samples back to the lab for analysis. However, on Kalymnos, each sample was air dried for at least 24 hours. Given that temperatures were over 90 Fahrenheit for the duration of my time on Kalymnos and that there was no rain until the day I left, the soils were dry at the end of this period. After air-drying, I used a $2 \mathrm{~mm}$ sieve to remove gravel, weighing each sample before and after so doing, in order to determine gravel percent. Following gravel removal, I hand textured each soil sample using the same method as above. This analysis was done in my studio using available space, with care given to avoid losses due to wind. Once the soil type was determined, I used the mid-point table created by Cosby et al. (1984) to determine the percent sand, silt, and clay of each sample.

DIGITAL ANALYSIS 
I downloaded the GPS data using Pathfinder software. I differentially corrected the data for both locations, but found that some of my Salmon-Huckleberry Wilderness sites were deleting during correction and that some of the Kalymnos sites were moved to the middle of Turkey. Hence, I imported the data without differentially correcting it. All Salmon-Huckleberry Wilderness sites had an associated point and all Kalymnos sites landed on Kalymnos. As a result of these findings, I used the non-differentially corrected data for both locations.

I attempted to determine contributing area using ArcGIS and the GPS point data, as has been done in previous studies (Jaeger et al. 2007). For the Salmon-Huckleberry Wilderness, I placed the points over a flow accumulation model I made using ArcGIS and a 1/3 Arc-second DEM from the National Elevation Dataset (USGS 2015). The first step in creating the flow accumulation model was making a fill layer. I then generated a flow direction layer from the fill layer. Finally, I created the flow accumulation model from the flow direction model. This general process has documented use in previous studies (Ariza-Villaverde et al. 2015).

Using the flow direction layer created as a step to generate the flow accumulation model, I delineated the watersheds for my points. These files were then converted to shape files, so that I could calculate the contributing area to each point. However, these calculations were ultimately not included in statistical analysis. The small size of the study watersheds in conjunction with the comparatively coarse DEM resolution exceeds the ability of the D8 algorithm, used by ArcGIS, to create accurate 
flow accumulation models (Ariza-Villaverde et al. 2015). Thus, watershed area derived via this method is circumspect.

In lieu of drainage area, I chose to measure the distance from my sites to the nearest drainage divide (Leopold et al. 1964). This choice is consistent with the aforementioned comments of Knighton's regarding the usefulness of this critical distance (1998) after having first been introduced by Horton (1945) in his working studying the formation of rills. After making this decision, I used the GPS generated points and ArcGIS's measure tool in order to determine the distance to drainage divide. The same measurement was done for the Kalymnos data. However, as no DEM with resolution greater than $\mathbf{3 0}$ meters is available for Kalymnos, the site information was placed atop georeferenced scans of a GPS verified topographic map of the island prior to measurement (Psimenos 2015). Using ArcGIS's measure tool, I calculated the distance to drainage divide for all study sites. This distance is measured using Euclidian distance from the GPS point upslope to the nearest ridgeline.

\section{STATISTICAL ANALYSIS}

In order to gain insight into the results of the above data collection, several statistical tests were run. After determining that the vast majority of the data are not normally distributed, Spearman correlations analysis was run. Then, data was put through a Mann-Whitely test to determine if the Salmon Huckleberry Wilderness data are significantly different from those on Kalymnos. Finally, stepwise regression analysis 
was preformed. Regression analysis was done for all sites collectively, then the Salmon Huckleberry Wilderness sites as a group, and lastly for all Kalymnos sites. 


\section{RESULTS}

In all instances in the Salmon-Huckleberry Wilderness, depth to bedrock exceeded the length of the trowel used to collect soil samples, making underlying lithology less relevant to this study than the parent material; however, all other site attributes are summarized in Table 1.

\begin{tabular}{|c|c|c|c|c|c|}
\hline \multicolumn{6}{|c|}{ Summary Table } \\
\hline Variable Type & Variable & Study Area & $\mathbf{N}$ & Median & $\begin{array}{l}\text { 2-tailed } \\
\text { SIGNIFICANCE }\end{array}$ \\
\hline \multirow{8}{*}{$\begin{array}{l}\text { Soil Variables } \\
{[\mathrm{g}]}\end{array}$} & \multirow{2}{*}{$\begin{array}{l}\text { \% Gravel in } \\
\text { sample * }\end{array}$} & Salmon Huckleberry & 23 & 21.1 & \multirow{2}{*}{0.003} \\
\hline & & Kalymnos & 20 & 58.8 & \\
\hline & \multirow{2}{*}{ Sand * } & Salmon Huckleberry & 25 & 51.9 & \multirow{2}{*}{0.000} \\
\hline & & Kalymnos & 20 & 17 & \\
\hline & \multirow{2}{*}{ Silt } & Salmon Huckleberry & 25 & 41.7 & \multirow{2}{*}{0.423} \\
\hline & & Kalymnos & 20 & 43 & \\
\hline & \multirow{2}{*}{ Clay* } & Salmon Huckleberry & 25 & 10.0 & \multirow{2}{*}{0.000} \\
\hline & & Kalymnos & 20 & 34 & \\
\hline \multirow{10}{*}{ Cover Type \% } & \multirow{2}{*}{ Bare * } & Salmon Huckleberry & 25 & 0 & \multirow{2}{*}{0.012} \\
\hline & & Kalymnos & 20 & 0 & \\
\hline & \multirow{2}{*}{ Litter * } & Salmon Huckleberry & 25 & 62.5 & \multirow{2}{*}{0.000} \\
\hline & & Kalymnos & 20 & 10.8 & \\
\hline & \multirow{2}{*}{ Gravel * } & Salmon Huckleberry & 25 & 0 & \multirow{2}{*}{0.000} \\
\hline & & Kalymnos & 20 & 16.7 & \\
\hline & \multirow{2}{*}{ Stone * } & Salmon Huckleberry & 25 & 0 & \multirow{2}{*}{0.000} \\
\hline & & Kalymnos & 20 & 50 & \\
\hline & \multirow{2}{*}{$\begin{array}{l}\text { Vegetation } \\
*\end{array}$} & Salmon Huckleberry & 25 & 38.3 & \multirow{2}{*}{0.000} \\
\hline & & Kalymnos & 20 & 15.9 & \\
\hline \multirow{2}{*}{\multicolumn{2}{|c|}{ Slope \% }} & Salmon Huckleberry & 25 & 96 & \multirow{2}{*}{0.222} \\
\hline & & Kalymnos & 20 & 103 & \\
\hline \multirow{2}{*}{\multicolumn{2}{|c|}{$\begin{array}{l}\text { Distance to Drainage Divide } \\
{[\mathrm{m}]}\end{array}$}} & Salmon Huckleberry & 25 & 6.97 & \multirow{2}{*}{0.664} \\
\hline & & Kalymnos & 20 & 7.6 & \\
\hline
\end{tabular}

Table 1. 
Slope

Local slope percent for the Salmon-Huckleberry Wilderness ranges from 82 to 233 percent, with the average slope being 110 percent. The standard deviation is 36 percent. On Kalymnos, slopes range from 85 to 333 percent with the average slope being 136 percent. The standard deviation is 68 percent.

\section{Soils: Organic Matter, Gravel Content, and Fine Earth Fraction}

While organic matter could not be measured on Kalymnos, it was measured for all but one site in the Salmon-Huckleberry Wilderness. The range of organic matter per sample is from 19 to 93 percent. It is possible that the sample with 93 percent organic matter is a bit overestimated because of the heavy duff layer. It is the third soil sample collected and inadequate litter removal may have led litter being included in the sample. Fine pine needles could have survived the $2 \mathrm{~mm}$ sieving process. Nonetheless, the average percent organic matter is 45 percent. Kalymnos soils most likely contain a far smaller percent organic matter given the ground cover observations detailed below. In the Salmon-Huckleberry Wilderness, gravel content in soil samples is generally high at an average of 28 percent of total soil sample. The range of gravel percentages is less than one percent to 92 percent. The highest percent gravel happens to coincide with the sample containing the greatest percentage of organic matter.

On Kalymnos the gravel content is even higher on average, at 56 percent. 
Interestingly, like the Salmon-Huckleberry Wilderness soils, the range is also large from 4 to 100 percent. However, only four of the twenty sites had less than 50 percent gravel content. Thus, it is fair to claim Kalymnos soils are higher in gravel content than those of the Salmon-Huckleberry Wilderness.

Examining the fine earth fractions overall, the soils of the Salmon-Huckleberry Wilderness are generally higher in sand content and lower in clay content than those of Kalymnos. The average sand and clay content for the Salmon-Huckleberry Wilderness is 50 and 11 percent, respectively. In contrast, for Kalymnos, sand is an average of 27 percent of the fine earth fraction, while clay is 30 percent. The Kalymnos averages exclude one site, which has no soil. Continuing to look at averages, the silt content for both locations is similar. Average silt percent for the Salmon-Huckleberry Wilderness is 39 and for Kalymnos it is 43.

Kalymnos soils are generally higher in clay and silt content than SalmonHuckleberry soils. At the same time, they are thin and low in organic matter as is expected in this arid environment (Schaetzl and Thompson 2015). It is possible that hand texturing over-estimated clay percent as has been noted to happen, "soils that contain large amounts of fine silt also seem to have a higher clay content than the value determined in the laboratory" (Soil Survey Field Manual, 57). Even if the clay percent was overestimated, Kalymnos soils, overall, have a finer texture. (Table 1).

\section{Vegetative Cover}


With regard to vegetative cover, it is important to note that, using the Daubenmire method; total cover percentages can exceed 100. (Table 1). For both study areas, bare ground is negligible (less than 1 percent for the Salmon-Huckleberry Wilderness and 2 percent for Kalymnos). Litter is present throughout both study areas, except for one site on Kalymnos. The same is true for vegetation. However, the one site lacking vegetation on Kalymnos is not the same site lacking litter.

For the Salmon-Huckleberry Wilderness, the average percent litter cover is 61 percent with 42 percent being the average amount of vegetation cover. Thus, the sites of the Salmon-Huckleberry Wilderness are generally fully covered by vegetation and litter. Meanwhile, on Kalymnos the average litter and gravel percentages are 12 and 17, respectively. Combined they only account for 28 percent of the surface cover.

Examining gravel and stone results exposes even more differences. Recall that gravel as a cover type is distinct from the percent gravel in present in the soil sample. Overall, gravel and stone cover are negligible in the Salmon-Huckleberry Wilderness, at two and one percent, respectively. This is a combined percentage of three. Yet, they account for a large portion of the Kalymnos ground cover. As with litter and vegetation, there is a variable amount of stone and gravel cover among the sites, but at each site their combined percentage exceeds 45 percent, at all but one site. Furthermore, the average gravel percentage on Kalymnos is 22 and stone is 51 percent. Combined they account for an average of 73 percent of the cover on Kalymnos. 


\section{Distance to Drainage Divide}

The average distance to drainage divide is 12.4 meters in the SalmonHuckleberry Wilderness. There was one outlier at 41.65 meters. This site is an outlier not only based on visual assessment in the field, but also because it is more than two standard deviations from the mean. Excluding the outlier, the distances to drainage divide range from 2.4 to 28.5 meters and the standard deviation is 8.5 meters.

On Kalymnos, distances to drainage divide range from 4.0 meters to 35.8 meters, with the average distance being 14.4 meters. The standard deviation is 11.9 meters.

\section{STATISITICAL ANALYSIS}

Statistical analysis of the compiled data reveal significant results. The following correlations exclude the site that is an outlier for distance to drainage divide in the Salmon-Huckleberry Wilderness. When looking at all the sites together, sand is negatively correlated with the distance to drainage divide, while silt is positively correlated.

For correlations analysis of the Salmon-Huckleberry Wilderness alone, organic matter was included. Here there are several correlations with distance to drainage divide. The percent gravel per soil sample and slope are both positively correlated with the distance to drainage divide. Looking at cover types, a positive correlation with bare ground and gravel is uncovered. On Kalymnos, only percent silt remains as a positive correlation with the distance to drainage divide (Table 2). 


\begin{tabular}{|c|l|c|c|}
\hline \multicolumn{3}{|c|}{ CORRELATIONS with DISTANCE TO DRAINAGE DIVIDE*** } \\
\hline SITES & \multicolumn{1}{|c|}{ VARIABLE } & $\begin{array}{c}\text { SPEARMAN } \\
\text { coefficient }\end{array}$ & 2-tailed SIGNIFICANCE \\
\hline All & Silt & 0.317 & 0.036 \\
\hline $\begin{array}{c}\text { Salmon-Huckleberry } \\
\text { Wilderness }\end{array}$ & Gravel \% cover * & 0.498 & 0.013 \\
\cline { 2 - 4 } & Stone \% cover * & 0.427 & 0.037 \\
\hline Kalymnos & Sand & -0.478 & 0.028 \\
\hline$*$ per Daubenmier & \multicolumn{3}{|c}{$* * *$ excludes outlier } \\
\hline
\end{tabular}

Table 2 - Correlation Results

In addition, the Mann-Whitney results (Table 3) reveal a significant difference between sites in the Salmon-Huckleberry Wilderness and those on Kalymnos for all soil variables (gravel, sand, and clay) except for silt. With regard to cover variables, all (bare ground, litter, gravel, stone, and vegetation) are significantly different. Given the similarities in average silt percent noted above, that silt content in the soil is not significantly different is unsurprising. What is a bit unexpected, in light of Montgomery and Dietrich's findings and theories suggesting that as hillslopes weather (move from transport limited to weathering limited) slope decreases, is the finding that slope and distance to drainage divide are not significantly different between sites, while almost all the other variables are significantly different (Table 1).

Using distance to drainage divide as the dependent variable with all others being independent, stepwise linear regression analysis, using SPSS, generates different results depending on how sites are grouped. Like the correlations, these regression results exclude the one site from the Salmon-Huckleberry Wilderness, which is an outlier for distance to drainage divide. Stepwise regression analysis of both study areas together 
produces a regression model with an $\mathrm{R}^{2}$ of .139 based on silt and .234 for combined silt and slope results (Tables $3 \& 4$ ).

\begin{tabular}{|c|c|c|c|c|c|c|c|}
\hline \multicolumn{8}{|c|}{ All Sites MODEL SUMMARY } \\
\hline \multirow[b]{2}{*}{ Model } & \multirow[b]{2}{*}{$\mathbf{R}$} & \multirow[b]{2}{*}{$\begin{array}{l}\text { R } \\
\text { Square }\end{array}$} & \multirow[b]{2}{*}{$\begin{array}{l}\text { Adjusted } \\
\text { R Square }\end{array}$} & \multirow[b]{2}{*}{$\begin{array}{l}\text { Std. Error of } \\
\text { the Estimate }\end{array}$} & \multicolumn{3}{|c|}{ Change Statistics } \\
\hline & & & & & R Square Change & $\begin{array}{l}\mathbf{F} \\
\text { Change }\end{array}$ & dr1 \\
\hline 1 & 0.373 & 0.139 & 0.177 & 8.85 & 0.139 & 6.451 & 1 \\
\hline 2 & 0.483 & 0.235 & 0.194 & 8.46 & 0.095 & 4.828 & 1 \\
\hline
\end{tabular}

Table 3 - All Sites Regression Models

\begin{tabular}{|c|c|c|c|c|c|}
\hline \multicolumn{6}{|c|}{ All Sites COEFFICIENTS } \\
\hline \multirow[b]{2}{*}{ Model } & \multicolumn{2}{|c|}{$\begin{array}{l}\text { Unstandardized } \\
\text { Coefficients }\end{array}$} & \multirow{2}{*}{$\begin{array}{c}\text { Standardized Coefficients } \\
\text { Beta } \\
\end{array}$} & \multirow[b]{2}{*}{$\mathbf{t}$} & \multirow[b]{2}{*}{ Sig } \\
\hline & B & Std. Error & & & \\
\hline 1 (Constant) & 2.457 & 4.304 & & 0.571 & 0.571 \\
\hline Silt & 0.256 & 0.101 & 0.373 & 2.540 & 0.015 \\
\hline 2 (Constant) & -7.120 & 5.992 & & 1.188 & 0.242 \\
\hline Silt & 0.320 & 0.101 & 0.465 & 3.179 & 0.003 \\
\hline Slope $\%$ & 0.056 & 0.026 & 0.322 & 2.197 & 0.034 \\
\hline
\end{tabular}

Table 4 - All Sites Regression Coefficients

For the Salmon-Huckleberry Wilderness alone, organic matter was included in the analysis, which results in $\mathrm{R}^{2}$ equal to .388 for gravel alone and .555 for gravel plus slope (Table 5 \& 6).

\begin{tabular}{|c|c|c|c|c|c|c|c|}
\hline \multicolumn{8}{|c|}{ Salmon Huckleberry Wilderness MODEL SUMMARY } \\
\hline \multirow[b]{2}{*}{ Model } & \multirow[b]{2}{*}{$\mathbf{R}$} & \multirow[b]{2}{*}{$\begin{array}{l}R \\
\text { Square }\end{array}$} & \multirow[b]{2}{*}{$\begin{array}{l}\text { Adjusted } \\
\text { R Square }\end{array}$} & \multirow[b]{2}{*}{$\begin{array}{l}\text { Std. Error of } \\
\text { the Estimate }\end{array}$} & \multicolumn{3}{|c|}{ Change Statistics } \\
\hline & & & & & R Square Change & $\begin{array}{l}\text { F } \\
\text { Change }\end{array}$ & dr1 \\
\hline 1 & 0.623 & 0.388 & 0.356 & 5.19 & 0.388 & 12.070 & 1 \\
\hline 2 & 0.745 & 0.555 & 0.505 & 4.55 & 0.166 & 6723 & 1 \\
\hline
\end{tabular}

Table 5 - Salmon Huckleberry Wilderness Regression Models 


\begin{tabular}{|c|c|c|c|c|c|}
\hline \multicolumn{6}{|c|}{ Salmon Huckleberry COEFFICIENTS } \\
\hline \multirow[b]{2}{*}{ Model } & \multicolumn{2}{|c|}{$\begin{array}{l}\text { Unstandardized } \\
\text { Coefficients }\end{array}$} & \multirow{2}{*}{$\begin{array}{c}\text { Standardized Coefficients } \\
\text { Beta } \\
\end{array}$} & \multirow[b]{2}{*}{$\mathbf{t}$} & \multirow[b]{2}{*}{ Sig } \\
\hline & B & Std. Error & & & \\
\hline 1 (Constant) & 9.953 & 1.222 & & 8.144 & 0.000 \\
\hline Gravel & 1.002 & 0.288 & 0.623 & 3.474 & 0.003 \\
\hline 2 (Constant) & 1.499 & 3.432 & & 0.437 & 0.668 \\
\hline Gravel & 0.749 & 0.271 & 0.466 & 2.766 & 0.013 \\
\hline Slope \% & 0.077 & 0.030 & 0.437 & 2.593 & 0.018 \\
\hline
\end{tabular}

Table 6 - Salmon Huckleberry Wilderness Regression Coefficients

Regression analysis of the Kalymnos sites only, results in $\mathrm{R}^{2}$ of .297 for silt (Table 7 \& 8).

\begin{tabular}{|c|c|c|c|c|c|c|c|}
\hline \multicolumn{8}{|c|}{ Kalymnos MODEL SUMMARY } \\
\hline \multirow[b]{2}{*}{ Model } & \multirow[b]{2}{*}{$\mathbf{R}$} & \multirow[b]{2}{*}{$\begin{array}{l}\mathbf{R} \\
\text { Square }\end{array}$} & \multirow[b]{2}{*}{$\begin{array}{l}\text { Adjusted } \\
\text { R Square }\end{array}$} & \multirow[b]{2}{*}{$\begin{array}{l}\text { Std. Error of } \\
\text { the Estimate }\end{array}$} & \multicolumn{3}{|c|}{ Change Statistics } \\
\hline & & & & & R Square Change & $\begin{array}{l}\text { F } \\
\text { Change }\end{array}$ & dr1 \\
\hline 1 & 0.545 & 0.297 & 0.258 & 10.27 & 0.297 & 7.604 & 1 \\
\hline
\end{tabular}

Table 7 - Kalymnos Regression Model

\begin{tabular}{|c|c|c|c|c|c|}
\hline \multicolumn{6}{|c|}{ Kalymnos COEFFICIENTS } \\
\hline \multirow[b]{2}{*}{ Model } & \multicolumn{2}{|c|}{$\begin{array}{l}\text { Unstandardized } \\
\text { Coefficients }\end{array}$} & \multirow{2}{*}{$\begin{array}{c}\text { Standardized Coefficients } \\
\text { Beta } \\
\end{array}$} & \multirow[b]{2}{*}{$\mathbf{t}$} & \multirow[b]{2}{*}{ Sig } \\
\hline & B & Std. Error & & & \\
\hline 1 (Constant) & -0.521 & 5.870 & & 0.089 & 0.93 \\
\hline Silt & 0.365 & 0.132 & 0.545 & 2.758 & 0.013 \\
\hline
\end{tabular}

Table 8 - Kalymnos Regression Coefficients 
DISCUSSION

Statistical analysis demonstrates what observation suggests, that the two study areas are significantly different from each other in nearly every measured parameter. In addition, analysis reveals that soil texture plays a significant role in the location of ephemeral flow concentration. The thick organic epipedon soils of the SalmonHuckleberry Wilderness are the result of dense coniferous vegetation, which is slow to decompose, and a low intensity precipitation regime combined with a relatively cool climate. Kalymnos soils' finer texture is due to a combination of factors. One factor is the limestone parent material, which dissolves through carbonation creating pockets that can protect silt and clay from wind and water erosion. A second is the proximity of Kalymnos to Turkey and North Africa, which makes it possible for some of the fine soil particles to have a provenance as aeolian deposits from these regions. Most importantly, the fine texture of Kalymnian soils indicates that the landscape is geomorphically older and more weathered than the Salmon-Huckleberry Wilderness (Schaetzl and Thompson 2015).

When assessing the relationships demonstrated via statistical analysis, some broad patterns emerge. As the percent of sand, silt, or clay increases one or both of the others must decrease, as the sum must always equal 100 percent (Schaetzl and Thompson 2015). Thus, one of the three is always negatively correlated with the others. Furthermore, the greater the percentage of clay and silt the less permeable the soil 
becomes. Conversely, the greater the sand content the more permeable the soil. Greater gravel percentages also equate to greater permeability. Put another way, the finer the soil texture, the less permeable it becomes. In fact, soils high in clay have a very low infiltration capacity and thus can be highly impervious (Dunne and Leopold 1978).

Connecting what is known of soil properties to study results, it is clear that the more impermeable the surface, the greater is the distance from the drainage divide to the point of ephemeral flow concentration. On Kalymnos, this is seen in the positive regression relationships with silt percent. The greater the silt content, the greater the required distance, which is simply another way of stating that the less pervious the soil matrix, the longer it takes for ephemeral flow to concentrate. Examining these results in light of flow type, it becomes clear that, in the weathering limited environment of Kalymnos, the highly impervious nature of bedrock in conjunction with the fine soil texture results in ephemeral overland flow being Hortonian in nature, regardless of slope. This finding is consistent with Knighton's (1998) observation that the conditions required for Hortonian overland flow are "most often achieved in semi-arid to arid areas with sparse vegetation and thin soils" (68).

Unpacking the results of the study for the Salmon-Huckleberry Wilderness is a bit more complex. However, they are more easily understood when considering flow type (Figure 1). Given the thick soil matrix of this transport limited study area, it is clear that the conditions for Hortonian overland flow are less likely to be met and that saturated 
overland flow will dominate. A component of saturated overland flow that is critical to understanding the regression results for the Salmon Huckleberry Wilderness is return flow (Figure 1, point 3). Return flow is the portion of saturated overland flow that results from water in the saturated soil matrix, which is being pulled downslope toward more saturated soil via gravity, to be forced back to the surface (Knighton 1998).

Regression results for the Salmon-Huckleberry Wilderness have both gravel and slope positively contributing to the distance from the drainage divide at which ephemeral flow concentrates. At first examination this may seem totally at odds with the findings from Kalymnos. As permeability increases, so does the distance from the drainage divide, which alone is the opposite of Kalymnos. Yet, saturated overland flow dynamics explain this result. With increased permeability there is more water in the soil matrix, which leads to a smaller amount of water moving overland than would if the soil were relatively more impermeable. Conversely, decreased permeability results in more water moving overland, which we know from our Kalymnos results and knowledge of Hortonian overland flow leads to ephemeral flow concentrating further from the drainage divide. However, permeability alone is not responsible for the location of ephemeral flow concentration in this transport limited environment.

Slope is working in conjunction with permeability in the Salmon-Huckleberry Wilderness to determine the location of ephemeral flow concentration. On steeper slopes, less water infiltrates and thus less water is available to ultimately become return flow. At the same time, as slope increases more water that has infiltrated into the soil 
matrix is forced to the surface as return flow due to higher hydraulic loading with increased rates of hydraulic conductivity. These two facets of saturated overland flow explain why as slope increases so too does the distance required for ephemeral flow to concentrate. Furthermore, this finding is in line with existing knowledge regarding saturated overland flow's greater dependency on topography (Knighton 1998).

Further evidence of the regional nature of ephemeral flow locations and flow type can be seen in the regression results for all the sites together. The regression includes silt, as on Kalymnos, and slope, as in the Salmon-Huckleberry Wilderness. Thus, it is clear locations of ephemeral flow are not determined by a single universal relationship. Rather regional factors, particularly with respect to overland flow type, as influenced by whether a landscape is weathering or transport limited, are key.

Based on $\mathrm{R}^{2}$ values, it is clear that none of the regressions fully explain the location of ephemeral flow concentration. Sediment quantity likely accounts for some of the variation statistically unaccounted for by these results. Field observations and the findings detailed above make it clear that the Salmon-Huckleberry Wilderness represents a transport limited environment, while Kalymnos represents a weathering limited one. In addition, the differences in findings per study area are consistent with Knighton's (1998) postulation that regardless of climate, soil properties are directly linked to the occurrence of Hortonian overland flow.

In spite of these nuances, regardless of soil composition, in a weathering limited environment, Hortonian flow will dominate the overland flow regime. Transport limited 
environments, given their more extensive soil mantle, will have greater saturated overland flow. Furthermore, this insight helps explain contradictory slope relationships found in previous studies (Henkle et al. 2011, Imaizumi et al. 2010, Jaeger et al. 2007, Julian et al. 2012). This study reveals that slope is more influential in transport limited environments with corresponding saturated overland flow dominant overland flow regimes. While in weathering limited environments slope appears to have a lesser impact. In 1980, Abrahams foreshadowed these results when he claimed that "it is hardly surprising that different researchers in different environments have obtained different results, and sometimes reached opposite conclusions regarding the role of ground slope," because "the geomorphic processes controlling channel initiation" vary (93).

As climate change continues to produce shorter duration, higher intensity precipitation events in many locations, as well as decreasing snow packs (Chang et al. 2010), areas of concentrated ephemeral flow are likely to play an increasingly significant role in water resource management. These areas will likely have greater flow with greater frequency and serve as sources of increased sedimentation as this higher velocity flow is able to move litter and soil that was previously unable to be moved by ephemeral flow. Furthermore, as erosion increases, these ephemeral channels will begin to incise. Although individual channels may show only slight change, the sum of increased erosion in all these headwater systems, which can occupy over $70 \%$ of the landscape (Lafrenz 2005), can collectively manifest large downstream effects. In so 
doing, it is likely they will become channel heads as traditionally defined by Montgomery and Dietrich as they develop clear banks. It is already accepted that "the location of the channel head shifts in response to climate and land use change" (Montgomery and Dietrich 1992, 828). In areas, like Kalymnos, which are already noted as particularly susceptible to climate change, these relatively small morphological changes could collectively prove a major concern in resource management (Kolokytha et al. 2011). In addition, if these ephemeral channel heads become channel heads as traditionally defined, they will become subject to existing legislation, even if the EPA study does not lead to ephemeral headwaters being legally protected.

Not only is climate change likely to have a profound impact on areas of concentrated ephemeral flow over time, but it is also likely that current land use practices, such as logging and paving, are already resulting in changes. Channel networks are impacted by changes in vegetation, increases in impervious surfaces, and groundwater extraction (Doyle and Bernhardt 2011). As a source of stream flow, areas of concentrated ephemeral overland flow are inevitably impacted as well. These future impacts will continue to remain difficult to elucidate until further research into the nuances of concentrated ephemeral overland flow brings greater clarity. Given the implications of the EPA's report on legislation, such as the Clean Water Act, locating ephemeral headwaters and their controls is a crucial first step toward mitigating anthropogenic impacts on these water resources. 


\section{CONCLUSIONS}

As a result of this study, it is clear that soil quantity and texture play a key role in the type of overland flow found in a given environment. Furthermore, flow type is critical to the location where ephemeral overland flow concentrates. These findings are in line with those of the Imaizumi et al. (2010) study that looked at sediment supply rates in relation to channel initiation. Their study found that flow types were the most important factor in driving channel head location. In addition, this study joins Imaizumi in answering Dietrich and Dunne's 1993 call for field work driven studies to test "transport 'laws' for runoff and sediment transport" (215).

Based on this study, two contrasting relationships driving the location of ephemeral flow concentration emerge. In the weathering limited environment of Kalymnos, overland flow is Hortonian in nature. As a result, as the soil matrix becomes less permeable or disappears altogether, ephemeral flow concentrates further from the drainage divide. On the other hand, in the transport limited environment of the Salmon-Huckleberry Wilderness, overland flow is predominantly saturated overland flow. In this case, permeability and slope work together to determine ephemeral flow concentration locations. As permeability and slope increase, there is a corresponding increase in the distance to drainage divide required for ephemeral flow concentration.

In spite of the regression analysis accounting for about half of the explained variability, it is likely a few improvements in data collection will strengthen the 
relationships. GPS points are likely to contain a significant amount of error due to the combined differential correction and multipath problems. In addition, the basemaps used to calculate the distance from drainage divide to these GPS points are of relatively low resolution. This challenge with remotely sensed data, when working at a fine scale is not unprecedented (Barbera and Roth 1997; Jaeger et al. 2007; Placzkowska et al. 2015; Vogt et al. 2003). Calculating distance to drainage divide in the field would resolve both problems and generate improved results. This recommendation is in line with that of Jaeger et al. (2007), who suggested that in spite of the extra work involved, "field surveys may provide the most practical method" for resolving current scalar issues (784).

In addition, flume studies that allow for full control of the independent variables would permit the inclusion of precipitation intensity and duration, which is likely a key driver of concentrated ephemeral flow. Given the range of variables included in this study, it is probable that nuances of precipitation regime primarily account for the variability not captured by regressing distance to drainage divide with the other measured variables.

Given the conclusion that flow type is the key to where ephemeral overland flow concentrates, it is likely that regional differences are the reason for the divergent conclusions of existing channel initiation studies. This would not be surprising given that many fluvial processes, including channel width and depth, are influenced by regional geomorphology (Leopold et al. 1964). While such models could prove helpful to land 
managers, given the fine scale of concentrated ephemeral flow their development demands a greater focus on local and regional variations (Montgomery 1999). It may be more prudent to focus future studies on precipitation regimes, soil texture, and, in transport limited environments, local slope. Greater understanding of regional precipitation regimes, as well as how they are changing, in conjunction with knowledge of sediment texture and quantity could open the door to the development of better models to predict the location of ephemeral flow. In addition, while creation of such models would incur the costs associated with fieldwork, the results would be highly accurate and not demand the expense associated with creating specialized very high resolution remotely sensed data.

These studies would then create the opportunity to construct mechanistic models for determining the location of ephemeral flow concentration. Once the location of ephemeral flow concentration is identified, appropriate land use management and protection practices can be employed. Knowing soil texture, slope, and precipitation information would allow managers to locate ephemeral headwaters. Taking it a stop further, managers could input projected precipitation information to generate models depicting the changes to the locations of concentrated ephemeral flow resultant form climate change. The power of being able to assess climate change impacts on the origins of water resources will likely outweigh its expense, particularly in more arid regions like Kalymnos. 
While this study was unable to develop a universal algorithm for predicting the location of ephemeral flow concentration, it sheds light on the relationship between soil properties, flow regime, and landscape evolution in the form of weathering versus transport limited environments. Furthermore, by using such distinct study areas, it shows that such a universal algorithm likely does not exist. In addition, it lays a solid foundation for continued work and a clear path forward in the investigation of landscape evolution. 


\section{REFERENCES}

Abrahams, A.D., 1980. Channel Link Density and Ground Slope. Mar. Association of American Geographers. 70(1), 80-93.

Ariza-Villaverde, A.B., Jimenez-Hornero, F.J., Gutierrez de Rave, E., 2015. Influence of DEM Resolution on Drainage Network Extraction: A Multifractal Analysis. April. Geomorphology. 241, 243-254.

Ballabio C., Panagos P., Montanarella L., 2016. Mapping topsoil physical properties at European scale using the LUCAS database. Geoderma. 261, 110-123.

Chang, H., Jung, I. 2010. Spatial and Temporal Changes in Runoff Caused by Climate Change in a Complex Large River Basin in Oregon. July. Journal of Hydrology. 388(3-4), 186-207.

Cosby, B.J., Hornberger, G.M., Clapp, R.B., Ginn, T.R., 1984. A Statistical Exploration of the Relationships of Soil Moisture Characteristics to the Physical Properties of Soil. June. Water Resources Research. 20(6), 682-690.

Daubenmire, R. F. 1959. A Canopy-Coverage Method. Northwest Science. 33, 43-64.

Davie, T., 2008. Fundamentals of Hydrology. Routledge, New York.

Dietrich, W.E., Dunne, T. The Channel Head. In: Beven, K., Kirkby, M.J. (Eds.), Channel Network Hydrology. John Wiley \& Sons Ltd.

Doyle, M.W., Bernhardt, E.S., 2011. What is a Stream? Environmental Science and Technology. 45(2), 354-359.

Dunne, T., Leopold, L.B., 1978. Water in Environmental Planning. W. H. Freeman and Company, New York.

Environmental Protection Agency, 2015a. 40 CFR Parts 110, 112, 116, et al. Clean Water Rule: Definition of "Waters of the United States" Final Rule. Federal Register. Jun. 80(124).

Environmental Protection Agency, 2015b. Connectivity of Streams and Wetlands to Downstream Waters: A Review and Synthesis of Scientific Evidence. Jan.

Gomi, T., Sidle, R.C., Richardson, J.S., 2002. Understanding Processes and Downstream Linkages of Headwater Systems. Oct. BioScience. 52(10), 905-916. 
Goulsbra, C.S., Lindsay, J.B., Evans, M.G., 2009. A New Approach to the Application of Electrical Resistance Sensors to Measuring the Onset of Ephemeral Streamflow in Wetland Environments. Water Resources Research. 45.

Greece.com, 2016. Kalymnos: A Climbing Paradise. http://www.greece.com/destinations/Dodecanese/Kalymnos.

Guyer, G., 2015. Figures and Tables.

Henkle, J.E., Wohl, E., Beckman, N., 2011. Locations of Channel Heads in the Semiarid Colorado Front Range, USA. Geomorphology. 129, 309-319.

Horton, R.E., 1945. Erosional Development of Streams and Their Drainage Basins: Hydrophysical Approach to Quantitative Morphology. Bulletin of the Geological Society of America. 56, 275-370.

Huggett, R.J., 1975. Soil Landscape Systems: A Model of Soil Genesis. Geoderma. 13, $1-22$.

Huggett, R.J., 2011. Fundamentals of Geomorphology. Routledge, New York.

Imaizumi, F., Hattanji, T., Hayakawa, Y.S., 2010. Channel Initiation by Surface and Subsurface Flows in a Steep Catchment of the Akaishi Mountains, Japan. Geomorphology. 115, 32-42.

Jaeger, K.L., Montgomery, D.R., Bolton, S.M., 2007. Channel and Perennial Flow Initiation in Headwater Streams: Management Implications of Variability in Source-Area Size. Environmental Management. 40, 775-786.

Julian, J.P., Elmore, A.J., Guinn, S.M., 2012. Channel Head Locations in Forested Watersheds Across the Mid-Atlantic United States: A Physiographic Analysis. 177/178, 194-203.

Kamm, H., 1984. Ode to Sponges: A Greek Isle's Heritage Dries Out. Oct 2. New York Times. A2.

Kechagias, E., Katsifarakis, K.L., 2004. Planning Water Resources Management in Small Islands. The Case of Kalymnos, Greece. Oct. Water, Air, \& Soil Pollution. 4(4), 279-288. 
Knighton, D., 1998. Fluvial Forms and Processes: A New Perspective. Oxford UP, New York.

Kolokytha, E.G., Traikapi, E.K., Mylopoulos, Y.A., 2011. Water Scarcity and Climate Change in Greek Islands. June/Jul. Engineers Australia. 2106-2112.

Lafrenz, Martin. 2015. Modified Micro-Pipette Method for Particle Size Analysis. Personal communication. Portland State University Geography Department Soil Lab.

Leopold, L.B., Wolman, M.G., Miller, J.P., 1964. Fluvial Processes in Geomorphology. Dover P Inc., New York.

Lowe, W.H., Likens, G.E., 2005. Moving Headwater Streams to the Head of the Class. Mar. BioScience. 55(3), 196-197.

Mimides, T., Psomiadis, E., Trikili I., 2007. Monitoring Land Use Changes and Soil Degradation Using SPOT and Temporal Aerial Photograph Data - The Case of the Vathy Basin (Kalymnos Island - Dodecanese Greece). May. Bulletin of the Geological Society of Greece. 40, 1476-1484.

Montgomery, D.R., 1999. Process Domains and the River Continuum. Apr. Journal of the American Water Resources Association. 35(2), 397-410.

Montgomery, D.R., Dietrich, W.E., 1988. Where do Channels Begin? Nov. Nature. 336, 232-234.

Montgomery, D.R., Dietrich, W.E., 1989. Source Areas, Drainage Density, and Channel Initiation. Aug. Water Resources Research. 25(8), 1907-1918.

Montgomery, D.R., Dietrich, W.E., 1992. Channel Initiation and the Problem of Landscape Scale. Feb. Science. 255(5046), 826-830.

Montgomery, D.R., Dietrich, W.E., 1994. Landscape Dissection and Drainage Area-Slope Thresholds. In: Kirkby, M.J. (Ed.), Process Models and Theoretical Geomorphology. John Wiley and Sons Inc., New York, 221-246.

Nadeau, T.L. 2015. Streamflow Duration Assessment Method for the Pacific Northwest. EPA 910-K-14-001. U.S. Environmental Protection Agency. Seattle, WA.

National Oceanic and Atmospheric Administration: National Weather Service, 2016. Advanced Hydrological Prediction Service. http://water.weather.gov/precip/\#. 
Peirce, S.E., Lindsay, J.B., 2015. Characterizing Ephemeral Streams in a Southern Ontario Watershed Using Electrical Resistance Sensors. Hydrological Processes. 29, 103111.

Placzkowska, E., Gornik, M., Ewelina, M., Peek, B., Potoniec, B.R., Siwek, J., 2015. Spatial Distribution of Channel Heads in the Polish Flysch Carpathians. Catena. 127, 240-249.

Psimenos, S., 2015. 1:25000. Kalymnos: Telendos. 337. Athens, Greece: Terrain.

Recreation.gov. Wildwood Recreation Site, OR. http://www.recreation.gov/campgroundDetails.do?contractCode=NRSO\&parkld $=74082$.

Roth, G., La Barbera, P., 1997. Morphological Characterization of Channel Initiation. Physics and Chemistry of the Earth. 22(3-4), 329-332.

Schaetzl, R.J., Thompson, M.L., 2015. Soils: Genesis and Geomorphology. Cambridge UP, New York.

Smith, T.R., Bretherton, F.P., 1972. Dec. Stability and the Conservation of Mass in Drainage Basin Evolution. Water Resources Research. 8(6), 1506-1529.

Soil Survey Staff, 2014. Soil Survey Field and Laboratory Methods Manual. Soil Survey Investigations Report No. 51, Version 2.0. R. Burt and Soil Survey Staff (ed.). U.S. Department of Agriculture, Natural Resources Conservation Service.

Tucker, G.E., Arnold, L., Bras, R.L., Flores, H., Istanbulluoglu, E., Solyom, P., 2006. Headwater Channel Dynamics in Semiarid Rangelands, Colorado High Plains, USA. Jul/Aug. GSA Bulletin. 118(7/8), 959-974.

USDA, 2016. Mt. Hood National Forest: Salmon-Huckleberry Wilderness. http://www.fs.usda.gov/recarea/mthood/recarea/?recid=79441.

USDA, 2015. Web Soil Survey. http://websoilsurvey.sc.egov.usda.gov/App/WebSoilSurvey.aspx.

USGS, 2015. National Map Viewer. http://viewer.nationalmap.gov/basic/?basemap=b1\&category=ned,nedsrc\&title $=3$ DEP\%20View. 
Vogt, J.V., Colombo, R., Bertolo, F., 2003. Deriving Drainage Networks and Catchment Boundaries: A New Methodology Combining Digital Elevation Data and Environmental Characteristics. Geomorphology. 53, 281-198.

Wilderness Institute, 2016. Salmon-Huckleberry Wilderness. http://www.wilderness.net/NWPS/wildView?WID=514.

Wohl, E., 2013. Migration of Channel Heads Following Wildfire in the Colorado Front Range, USA. Earth Surface Processes and Landforms. 38, 1049-1053.

World Weather and Climate Information, 2016. Average Weather and Climate in Greece. https://weather-and-climate.com/average-monthly-RainfallTemperature-Sunshine-in-Greece. 